\title{
PRICE INCREASES DURING THE PANDEMIA AND EU COMPETITION LAW
}

\author{
Prof. Avv. Emiliano Marchisio, LL.M., PhD, Associate Professor \\ "Giustino Fortunato" University of Benevento \\ Viale Raffaele Delcogliano, 12, 82100 Benevento, Italy \\ emiliano.marchisio@gmail.com
}

\begin{abstract}
The debate about the "just price" has ancient origin and returns forcefully to the scene when, in the event of crises of various kinds, there is a rapid and significant increase in prices of given goods or services. In this article it is examined the problem of whether price increases of such a nature could, or should, be considered illicit under EU competition law. The central part of the article reviews different theories on what a "just price" should be and focuses on the idea that a price is "just" when it functions as index of relative scarcity in free markets. It is claimed that such a function deserves protection by EU law. Therefore, price adjustments in response to shocks cannot and should not be considered illegal: it is unacceptable to sanction private firms by attributing them the wrong of not having substituted, at their own expense, for the exercise of a public function (that of making sure that price increases do not put at risk solidarity and other constitutional principles).
\end{abstract}

Keywords: Just price; Competition Law; Collusion; Abuse; Dominant Position; Price Gouging

\section{INTRODUCTORY REMARKS ON THE PROBLEM OF THE "JUST PRICE". THE SPECIAL CONCERN SHOWN BY THE EU COMMISSION ON THE ISSUE OF PRICE INCREASES.}

The debate about the "just price" of goods and services has ancient origins and its traces may be found already in ancient Babylonian inscriptions. ${ }^{1}$ It is, however,

Baldwin, J.W., The Medieval Theories of the Just Price: Romanists, Canonists, and Theologians in the Twelfth and Thirteenth Centuries, American Philosophical Society, Philadelphia, 1959, p. 8. 
always actual ${ }^{2}$ and returns forcefully to the scene when, in the event of crises of various kinds, there is a rapid and significant increase in prices of given goods or services. This is currently (at the moment this article is being written) happening with respect to the crisis induced by the coronavirus pandemic.

As far as prices and competition law are concerned, it is noteworthy that the European Commission committed itself not to show any tolerance to attempts to exploit the crisis as a cover for anti-competitive collusion or abuses of dominant position "by, for example, exploiting customers and consumers (e.g. by charging prices above normal competitive levels)". ${ }^{3}$ The European Competition Network, in its Joint Statement, equally identified excessive pricing as a particular area of concern: "it is of utmost importance to ensure that products considered essential to protect the health of consumers in the current situation (e.g. face masks and sanitising gel) remain available at competitive prices". ${ }^{4}$

These concerns on price increases are certainly understandable, since they may bring influence not only on economic efficiency but also on public health and eventually on human lives. There is also a somehow emotional disappointment following any price increase during a crisis. The point, however, is not if price increases are abstractly desirable (as such they are not, of course) but whether contrasting price increases is the best path of action or not. Such a question may be answered only after a reflection of what prices are and how they work in capitalistic markets.

2 Although with less interest in the legal literature. Among others, reference can be made to Perrone, A., Doctrine of the right price and contemporary contract law. Some preliminary reflections, in: Campobasso, M.; Cariello, V.; Di cataldo, V.; Guerrera, F.; Sciarrone Alibrandi, A. (eds.), Companies, banks and business crises. Liber amicorum Pietro Abbadessa, Utet, Torino, 2014, pp. 81 ff.; Mccall, J., Learning from Our History: Evaluating the Modern Housing Finance Market in Light of Ancient Principles of Justice, South Car. Law Rev., 2009, pp. 707 ff.; Di Matteo, L.A., Equitables Law of Contracts: Standards and Principles, Transnational Publishers, Ardsley (NY), 2001, 259 ff..

3 Communication from the EU Commission of 8 April 2020, Temporary Framework for assessing antitrust issues related to business cooperation in response to situations of urgency stemming from the current COVID-19 outbreak, C(2020) 3200 final, $\$ 20$, in https:/ec.europa.eu/info/sites/info/files/framework_communication_antitrust_issues_related_to_cooperation_between_competitors_in_covid-19. pdf, hereinafter the EU Commission Firms Cooperation Temporary Framework. On these issues, especially as regards excessive pricing and price gouging, see: Cary, G.S. et all., Exploitative abuses, price gouging \& COVID-19: The cases pursued by EU and national competition authorities, 30 April 2020, e-Competitions Competition Law \& Covid-19, Art. No 94392; Lazda, A.R.B. et all., The World's Authorities present steps to minimise the impact of COVID-19 on antitrust related issues that businesses may confront in the coming days of the outbreak, 9 March 2020, e-Competitions Preview, Art. N 93889.

4 European Competition Network, Join Statement, 23 March 2020, in https://ec.europa.eu/competition/ecn/202003_joint-statement_ecn_corona-crisis.pdf. 
The subject matter is very wide and rich in articulations. For the sake of simplicity, I propose to delimit the field of investigation to competition law ${ }^{5}$, excluding, among others, consumer protection legislation and legislation against price gouging - which will be referred to anyway in a few instances.

I further propose, for the purpose of this article, to limit attention to the markets not subject to any special sector discipline. The following are therefore excluded, by way of example: markets where the nature of the goods or services exchanged prevent "general" competition law from applying (military defense, police services etc.); where determination of prices is subject to administrative measures to protect constitutionally interests prevailing over competition ("essential" goods and services etc.); where demand and/or supply of goods or services is subject to public incentives through grants, tax measures or the like; where containment criteria are imposed on prices (cap on interests under usury law etc.).

\section{PRICE INCREASES AND COMPETITION LAW.}

The inquiry on what prices are and how they work in capitalistic markets, in order to assess whether contrasting price increases during crises is the best path of action in EU competition law or not, needs be anticipated by a brief recalling of

The role of competition law in times of crisis is interpreted in very different ways. On the one hand, some Authors believe that enforcement of competition law should not adapt to crisis in any way: Lowe, P., Keeping Markets Working Effectively: Europe's Challenge in Recessionary Times, European Competition Day, Brno, 14.5.2009; Kroes N., Competitiveness - The Common Goal of Competition and Industrial Policies, Address at the Aspen Institute (Apr. 18, 2008); Shapiro, C., Competition Policy in Distressed Industries, speech delivered at the ABA Antitrust Symposium: Competition as Public Policy, 13.5.2009. Other Authors, adopting the same approach, believe that, at least, no relevant adaptation should be pursued; see, e.g.: Drauz, G. et all., Recent Developments in E.C. Merger Control, Journal of Eur. Comp. Law \& Pract., 2010, 1, p. 19. Other Authors, on the other hand, believe that competition law should take into account the problems caused by economic crisis: see, on this issue, Kokkoris, I. et al., Antitrust Law amidst Financial Crises, C.U.P., Cambridge, 2010.

In general, on the role of competition law in times of crisis, among many, see: Derenne, J.; Merola, M.; Rivas, J. (eds.), Competition law in times of economic crisis : in need of adjustment?, GCLC Annual Conference Series, Bruylant / LGDJ, 2013; Brenner, Y.S., Capitalism, Competition and Economic Crisis: Structural Changes in Advanced Industrialized Countries, Wheatsheaf Books, 1984; Padilla, J. et al., Competition policy and the Covid-19 opportunity, 20 April 2020, Concurrences $N^{\circ} 2-2020$, Art. $N^{\circ}$ 94317.

See also, with reference to the past financial global crisis (but with hints applicable also in these times): Crane, D., Antitrust Enforcement During National Crises: An Unhappy History, in GCP - The Online Magazine for Competition Policy, 15.12.2008; Sokol, D., The Financial Crisis and its Effects on Antitrust, in Antitrust \& Competition Policy Blog, 18.12.2008; Harris jr., H.S. et all., China: Korea Considers Antitrust Exemptions for Certain Cartels to Assist Economic Recovery, in www.mondaq.com, Jan. 2009; Katz, M. et all., Antitrust in a Financial Crisis - A Canadian Perspective, in www.antitrustsource.com, Apr. 2009; Addy, G. et all., Antitrust Legislation and Policy in a Global Economic Crisis - A Canadian Perspective, in GCP - The Online Magazine for Global Competition Policy, 15.12.2008. 
the conditions under which it is possible to sanction, under EU competition law, price increases.

\subsection{Price increases up to an "excessive" level as an exploitative abuse under art. 102 TFEU.}

The first hypothesis of interest under EU competition law relates to an increase in price amounting to an exploitative abuse consisting in excessive pricing. This may amount to a violation of competition law, under art. 102 TFEU, only insofar as the firm charging "excessive" prices has within the relevant market a dominant position. It ought to be noted that, given the interventionist attitude shown above with respect to the COVID-19 pandemic, it is likely that the EU Commission might adjust the definition of "dominance" in order to reach an higher number of firms, e.g.: defining the relevant markets more narrowly, in order to allow an easier finding of dominance therein; recognizing relevance also to temporary dominance $\left(^{6}\right)$; finding a collective dominant position in order to ascribe dominance to more competing firms $\left({ }^{7}\right)$; admitting excessive pricing as an indicator of dominance $\left({ }^{8}\right)$, even if this clearly represents a logical contradiction (in fact, only after dominance is assessed excessive pricing assumes relevance for competition law). ${ }^{9}$

The EU Commission has charged "excessive pricing" very rarely in the past and Advocate General Wahl suggested that EU Commission should be "extremely reluctant" to pursue exploitative abuse cases. ${ }^{10}$ However, the crisis induced by the COVID-19 pandemic, along with the interventionist attitude already recalled, is

$6 \quad$ An example of such an approach, see: Commission Decision n. 77/327/EEC of 19 April 1977 relating to a proceeding under art. 86 of the EEC Treaty (IV/28.841 - ABG/Oil companies operating in the Netherlands), in OJ L 117, 9.5.1977, p. 1.

7 It ought to be noted that the concept of "collective dominance" appears to be somehow abused in competition law reasoning since its applications, aimed at fighting anticompetitive outcomes of oligopolistic markets, are sometimes contradictory and not solidly grounded. The issue cannot be appropriately deepened here; with respect to such problem reference may be made to Marchisio, E., Critical Remarks on Collective Dominant Position in EU and Italian Antitrust Law, in ECLR, 2013, 11, pp. 559 ff..

8 In fact, "the Commission considers that an undertaking which is capable of profitably increasing prices above the competitive level for a significant period of time does not face sufficiently effective competitive constraints and can thus generally be regarded as dominant", as stated in the Communication from the Commission - Guidance on the Commission's enforcement priorities in applying Article 82 of the EC Treaty to abusive exclusionary conduct by dominant undertakings (2009/C 45/02), $\$ 11$.

9 Cary, G.S. et all., op. cit., note 3.

10 As noted by AG Wahl, "the Commission has been extremely reluctant to make use of that provision against (allegedly) high prices practiced by dominant undertakings. Rightly so, in my view. In particular, there is simply no need to apply that provision in a free and competitive market: with no barriers to entry, high prices should normally attract new entrants. The market would accordingly self-correct": Opinion of AG Wahl 
likely to allow the "excessive price" doctrine a wider recognition in EU competition law, as one may desume after reading the EU Commission's Temporary Framework and the European Competition Network's Joint Statement, mentioned above.

One of the problems in application of this prohibition lies in its very definition: since reaching a dominant position by endogenous growth (i.e.: not through a merger) is not prohibited under EU competition law and dominance implies application of prices above the competitive level by definition ${ }^{11}$, prohibition of prices above the competitive level by dominant firms amounts, as such, to an irrational and anti-economic imposition in patent contradiction with competition law which cannot prescind, in its application, from economic theory.

In order to (try to) solve such problem, EU competition law developed a test of "excessive" pricing rooted in the idea that a price is exploitative if "it has no reasonable relation to economic value of the product supplied" and based on two variables: whether the price is excessive when compared to the costs the firm actually incurs and whether it is "unfair in itself" or when compared to competing products. ${ }^{12}$

Such a definition appears, in itself, ill-grounded, since it is not clear what the "economic value" of a product should be apart from its price and what "unfair in itself" should mean. Application of these standards (price much higher than cost of production and "unfairness" thereof) would imply, among others, that almost all prices charged within luxury markets could be easily found "excessive". Besides these considerations, the above recalled test was developed in United Brands, which related to the distribution sector, where comparison between purchase and resell price is rather simple; this would not be the case in many other instances.

This is why EU competition law has been showing an attempt to develop further elements in order to charge "excessive pricing", e.g.: whether the price increase is drastic and sudden long after the product was originally launched; the increase is not caused by an increase of production costs or other market development; the demand is elastic or anelastic and to what extent; whether there are barriers to entry preventing potential competitors from entering the relevant market. ${ }^{13}$

These criteria show that, under EU competition law, a charge for exploitative abuse could be grounded only insofar as, among others, it may refer to a clear

\footnotetext{
in Case C177/16, Biedrība 'Autortiesību un komunicěšanās konsultāciju ağentūra - Latvijas Autoru apvienïba' $v$ Konkurences padome, ECLI:EU:C:2017:286, $\$ 3$.

11 Case C-27/76 United Brands v Commission, ECLI:EU:C:1978:22, \$65.

12 United Brands (see footnote n. 11), $\$ 250$; see also Case C-26/75 General Motors v Commission, ECLI:EU:C:1975:150, $\$ 12$.

13 Cary, G.S. et all., op. cit., note 3.
} 
benchmark consisting in the prices charged by the same dominant firm either in the past or in other geographical markets (e.g.: in other countries). ${ }^{14}$

\subsection{Price increase due to collusion falling within art. 101(1) TFEU.}

A price increase may be considered prohibited under EU competition law also when it is carried on by more firms and such an increase is a consequence of collusion between them, either in the form of an agreement or as a concerted practice. In this respect one should note that any collusion on prices (not only aimed at charging higher prices) would fall within the prohibition set forth in art. 101(1) TFEU. It should also noted that even with respect to application of art. 101(1) TFEU it is required that the relevant firms hold some market power, even if not amounting to dominance. ${ }^{15}$

Under EU competition law, moreover, any agreement on price increases would be prohibited as such, even if it did not determine any increase in fact, since art. 101(1) TFEU contains a prohibition of all agreements between undertakings, decisions by associations of undertakings and concerted practices which have "as their object or effect" the prevention, restriction or distortion of competition within the internal market, so that an anticompetitive object is enough to fall within art. 101(1) TFUE even if no effect follows. ${ }^{16}$

In absence of an agreement, however, a parallel increase of prices would not be sufficient in order to charge competing firms with a concerted practice. It is true, on the one hand, that such concept lies on the principles under which any firm must determine its commercial conduct independently ${ }^{17}$ and competing firms must not knowingly substitute for the risks of competition practical cooperation between them. ${ }^{18}$

14 Libertini, M., Diritto della concorrenza dell'Unione Europea, Milano, Giuffrè, 2014, p. 313. E.g., with respect to prices charged in other member States, see: Joined Cases 110/88, 241/88 and 242/88, François Lucazeau and others v Société des Auteurs, Compositeurs et Editeurs de Musique (SACEM) and others, ECLI:EU:C:1989:326.

15 See European Commission, Notice on agreements of minor importance which do not appreciably restrict competition under Article 101(1) of the Treaty on the Functioning of the European Union (De Minimis Notice) (2014/C 291/01). Even if price fixing are considered hardcore restrictions not benefiting from the De minimis notice, nevertheless art. 101(1) TFEU requires that agreements, decisions and concerted practices may affect trade between member States - which would not be the case if the overall market share of the concerned competitors was irrelevant.

16 On the issue see the Opinion of AG Bobek in Case C228/18, Gazdasági Versenyhivatal $v$ Budapest Bank Nyrt. and others, ECLI:EU:C:2019:678, \$25.

17 Joined cases C-40-48, 50, 54-56, 111, 113-114/73, Suiker Unie et all. v Commission, ECLI:EU:C:1975:174, $\$ 173$.

18 Suiker Unie (see footnote n. 17), IS 26; Case C-49/92 P, Commission v Anic Partecipazioni, ECLI:EU:C:1999:356, $\$ 115$. 
However, on the other hand, competition law cannot undermine the "right ... to react intelligently to the known or foreseeable behaviour of competitors". ${ }^{19}$ Article 101(1) TFUE, in fact, recognizes the right of enterprises to adapt intelligently to the conduct of their competitors in the relevant market and this is so with respect to both past and foreseeable behaviour. ${ }^{20}$ As an example, price adaptation following a price increase carried on by a price maker firm would not be considered, alone, as falling within art. 101(1) TFEU; likewise, a price increase within an oligopolistic market could be just the result of oligopolistic dependence, insofar as price competition may not exist as a natural consequence of oligopolistic markets. ${ }^{21}$ This is so true that price increases are considered as a signal of collusion only insofar as they are accompanied by other elements, especially signalling strategies aimed at reciprocal coordination. ${ }^{22}$

Said in other words: parallelism is a mere fact; it can amount to a violation of competition law only insofar as it is characterised by collusion - which could result from endogenous or exogenous elements of proof and even in the mere exchange or unilateral communication of commercially relevant information, in this case even irrespective of parallelism under the so-called Anic presumption as interpreted by the ECJ. ${ }^{23}$

This means that a price increase brought about by competing firms could be considered falling within art. 101(1) TFEU only insofar as it is proven that such increase is a consequence of collusion. It is clear, in this respect, that under art. 2 of Council Regulation (EC) No 1/2003 of 16 December 2002, "the burden of proving an infringement of Article [101](1) or of Article [102] of the Treaty shall rest on the party or the authority alleging the infringement". Such a conclusion is strongly underpinned by the presumption of innocence $\left({ }^{24}\right)$, which indubitably applies to

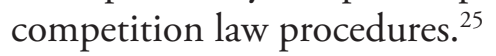

19 Suiker Unie (see footnote n. 17), \$173.

20 See Case C-199/92 P, Hüls AG v Commission (Polypropylene), ECLI:EU:C:1999:358; Case C48/69, Imperial Chemical Industries Ltd. v Commission (Dyestuff), ECLI:EU:C:1972:70; Suiker Unie, cit; Case 172/80, Züchner v Bayerische Vereinsbank, ECLI:EU:C:1981:178.

21 Whish, R.; Bailey, D., Competition Law, VIII ed., Oxford University Press, 2015, p. 603.

22 Dyestuff, cit., $\$ \$ 66$ and 100-103.

23 Marchisio, E., From concerted practices to "invitations to collude", in ECLR, 2017, p. 555.

24 On this issue see Opinion of AG Wahl, cit., $\$ 94$. It ought to be noted that the principle of the presumption of innocence is laid down in Article 48(1) of the Charter of Fundamental Rights of the European Union.

25 Polypropylene, cit., $\$ \$ 149$ f.; Case C-235/92 P, Montecatini v Commission, ECLI:EU:C:1999:362, \$\$ $175 \mathrm{f.}$. 


\subsection{Price increase in its own and the (assumed) problem of the "just" price.}

Both the cases recalled above, under artt. 101(1) and 102 TFEU, consider it relevant the concept of "just" price. Art. 102 TFEU is explicit in this sense insofar as its application requires, in order for a price increase to be considered as an abuse, that such increase represents a departure from a benchmark of "just" price which need be created with respect to prices applied in the past, by competitors, in foreign markets etc.

Such a condition is not expressly postulated in the application of art. 101(1) TFEU but it would be considered as a relevant feature thereto, insofar as parallel behaviour may amount to strong evidence of a concerted practice "if it leads to conditions of competition which do not correspond to the normal conditions of the market", in particular when prices result charged "at a level different from that to which competition would have led". $\left({ }^{26}\right)$ Therefore, a sound definition of what "just" price should (or might) mean is undoubtedly relevant also to art. 101(1) TFEU enforcement.

The opportunity appears favourable, therefore, to reflect on what meaning should be given to the concept of "just price" within EU competition law. In fact, only after such definition is clearly stated it seems possible to interpret, in functionally correct terms, the existing disciplines intended to prevent those prices move away from their "right" level.

\section{THE "JUST" PRICE AND THE CRITERIA FOR DEFINING IT IN ECONOMIC THEORY (AND NOT ONLY).}

The different ideas of "just" price elaborated over time, and conflicting at any given time, may be summarily grouped, for the purposes of this research, into three groups, the last of which presents, in turn, an internal articulation into two sub- groups.

\section{1. "Justice" on the demand side. Reference to this concept in "exploitative pricing" doctrine and "price gouging" legislation.}

The first conceptual reference to price "justice", historically more antique, places the emphasis on the buyer and his purchasing possibilities; on the "demand" side, one might say.

26 Dyestuff, cit., \$\$ 66-67. 
It is not surprising to find references thereto in the Bible and in the Talmudic literature. ${ }^{27}$ Within the Holy Scriptures the expression "just price" never appears (as far as I know). However, the need of a "fair" correspondence between what is paid and what is obtained in exchange is immanent in the text when "right weight", the "right measure" and the "right proportion" are referred to. ${ }^{28}$ This is consistent with the numerous biblical references to "justice" in human action, requiring the right man to do what is "legitimate and just" ${ }^{29}$, to correspond to the servants what is "just and fair" ${ }^{30}$ and, in generally, to follow what is "overall just". ${ }^{31}$

Historically, such an idea of justice has been accompanied by the ancient suspicion against traders and merchants - which has declined over the centuries as a real contempt for profit, commerce and trade. This vision has been well represented since Aristotle, author of one among the first elaborations of fair value in commercial exchange, widely used "as a philosophical justification for the medieval doctrine of the just price". ${ }^{32}$ In fact, many of the early church fathers, like Aristotle (with reference, in particular, to the Nicomachean Ethics), have considered trade as an activity to be viewed with suspicion, as it is moved by greed. This opinion was further supported by the idea that the profit of a party must necessarily correspond to the loss of the other. "He who buys cheaply to sell dearly, seeks a shameful profit", in short, and "it is difficult for buyers and sellers not to fall into sin". ${ }^{33}$

It is useless to even try a summary review of the literature which, up to the present day, continues to indulge in this ancient and always lively condemnation of profit. The basic theoretical idea of this approach is that one is able to define the "just value" of anything and that an exchange for any price not corresponding to such a "just value" should be considered immoral and illegal. ${ }^{34}$ Of course, notwithstanding the assumption, one cannot find any definition of what such a "just" value should be if not, tautologically, with reference to the current market price ("secundum commune forum"35).

\footnotetext{
27 Kleiman E., Just Price in talmudic Literature, in Hist. Polit. Econ. 1987, pp. 23 ff..

28 See Leviticus 19:36; Deuteronomy 25:15; Proverbs 11: 1, 16:11; Ezekiel 45:10.

29 Ezekiel 18:5.

30 Colossians 4:1.

31 Deuteronomy 16:20.

32 Baldwin, J.W., op. cit., note 1, p. 10.

33 Baldwin, J.W., op. cit., note 1, p. 47.

34 St. Thomas, Summa Theologiae, 1273. II-II, q. 77, a.1 co. 1.

35 St. Thomas, op. cit., note 34, II-II, q. 77, a.4c. On St. Thomas's reflection on prices see, for example: de Roover, R., The Concept of the Just Price: Theory and Economic Policy, in Journ. Econ. Hist., 1958, pp. 422 f.; Noonan jr, J.T., The Scholastic Analysis of Usury, Harvard University Press, Cambridge (MA), 1957, pp. 82 ff.; Ambrosetti, G., La seconda scolastica nella formazione del diritto privato moderno, in
} 
If one wants to summarize in a few words the above-examined approach, the idea of "just price" on the demand side represents a concept aimed at solving problems of distributive nature. In other words: it serves to allow fair access to goods and services by the largest number of buyers. The concept is far from obsolete, if one thinks, among others, of the use of so-called "political" or "administrated" prices, defined sometimes at a lower level even of production costs and supplemented with proceeds of taxation (or other form of subsidization), still in recent times used to support access to goods or services deemed "essential" for the population. ${ }^{36}$

The idea that a price is "just" insofar as it is and remains affordable for buyers lies behind the prohibition, imposed on dominant firms under EU competition law, to charge high prices which are exploitative, as noted above, under $₫ 2.1$. This principle also underpins the so-called price gouging regulations which one may find, e.g., in the USA, where competition law does not deal with excessive pricing at the federal level ${ }^{37}$ and price increases are sanctioned by state legislation, instead, which prohibits price increases, beyond what is considered "reasonable" or "fair" 38 , in certain situations, such as a declared state of emergency. ${ }^{39}$

However, such an approach to "just prices" plays a role only within the tiny limits of regulated markets and is unsuitable for providing any criterion for understanding the matter in general terms.

Grossi, P. (ed.), Quaderni fiorentini per la storia del pensiero giuridico moderno, Milano, Giuffrè, 1973, p. 28.

36 Think of the so-called "enhanced protection service" which, in the Italian energy market, represents the option that allows the consumer to purchase electricity and gas under the economic and contractual conditions established by the Regulatory Authority for Energy, Networks and Environment (ARERA, established by 1.14 November 1995, n. 481), instead of at the free market rates. On this subject see, among others: Smerchinich, F., Il mercato dell'energia elettrica: descrizione, funzionamento e dinamiche, in Riv. it. dir. pubbl. comunitario, 2017, pp. 1269 ff.; Palmieri, A., Somministrazione di energia elettrica e servizio di maggior tutela per l'utente, Nota a ord. Trib. Nola 15 novembre 2010, in Foro it., 2011, I, pp. 246 ss..

37 In fact, the US competition law approach to the issue is inspired by laisser faire, under which action against high prices is not antitrust but regulatory action, instead. In this respect, the Supreme Court stated that high, or even monopoly, prices are compatible with the competitive process and foster innovation and entry of potential competitors into the relevant market, in Trinko: US Supreme Court, Verizon Communications Inc. v. Law Offices of Curtis V. Trinko, LLP, 540 U.S. 398 (2004), 13.1.2004.

38 A useful short review of such pieces of legislation may be found at https://www.clearygottlieb.com/ news-and-insights/publication-listing/exploitative-abuse-of-dominance-and-price-gouging-in-timesof-crisis, where it is noted that there is no uniform threshold for what constitutes an "unreasonable" price, since some states fix the threshold at a $10 \%$ increase from previous prices; other states make reference to vague criteria such as prices that "grossly" exceed the average.

39 Lazda, A.R.B. et all., op. cit., note 3. 


\section{2. "Justice" on the supply side. Reference to this concept in the "essential facility" doctrine.}

The second conceptual reference on "just price" represents, in some ways, the reciprocal version of the first one. Moving from the "demand" side to the "supply" side, in effect, it is believed that a price could be defined "just" insofar as it sufficiently remunerates the production factors along with the entrepreneur's organizational activity and business risk.

According to this view, the price is interpreted as a sum of the costs borne by the entrepreneur for the production and distribution of goods or for the provision of services, increased of a surplus intended to remunerate the "entrepreneurial factor".

This reconstruction had the best known formulation in the anchorage of the price of goods or services to the amount of work necessary for their production. David Ricardo, for example, in his work On the Principles of Political Economy and Taxation (1817), believed that the exchange value of any good depended on the difficulties of producing it and, in particular, on the amount of work necessary to obtain it. It ought to be noted that Ricardo expressly defined this principle as an approximation, sufficient to describe the economic phenomena covered by his inquiry (for example: to justify the observation that the extension of the cultivation of wheat to relatively less fertile lands determined a relative increase of the price of wheat).

Again, this reconstruction is still alive and in use in modern thought. It suffices to note that the absolutisation of the Ricardian above-mentioned "approximation" represents the cornerstone on which the the theory of the exploitation of the proletariat by the capitalist classes, developed by Karl Marx in Das Kapital. Kritik der politischen Ökonomie (1867-1894), is based. Likewise, it ought to be noted that definition of prices based on the sum of production costs plus a markup is sometimes used in regulation for the determination of "administered" prices. ${ }^{40}$

In a very few cases such a criterion is referred to in EU competition law in order to define "fair" prices, as it happens, e.g., with reference to the essential facility doctrine (under which fair access price are required).$^{41}$ In these cases, one should note,

40 See, e.g.: Bassi G., Prezzi e tariffe nei servizi di pubblica utilità: cenni sull'evoluzione ordinamentale, in App. e contr., 2016, pp. $74 \mathrm{ff}$.; Ziliotti, M., I prezzi di accesso alle reti dei servizi di pubblica utilità: una sintesi teorica, in Econ. e pol. Ind., 2007, pp. $147 \mathrm{ff}$. .

41 An essential facility is a facility or infrastructure which is necessary for competitors in order to carry on their business. A facility is essential if its duplication is impossible or extremely difficult because of physical, geographical, legal or economic constraints. Denying access to an essential facility may be 
the concept of fairness is construed not only on price levels as such but also relates to (the need to prevent) discrimination between buyers and cross-subsidising. ${ }^{42}$

This definition, however, bears, like its mutual formulation on the demand side, the total arbitrariness in the definition of the reference parameter; in this case, of what the "just" remuneration of the organizational factor should be. In fact, a survey of profit margins practiced by firms may represent, at most, an empirical support for verifying if prices charged at a given moment fall within the market average; it would not provide any useful contribution to define what the "just" level of prices should be on the market, though.

\section{3. "Justice" as the encounter of supply and demand curves.}

The third conceptual reference on "just price" represents, compared to the first two examined above, a conceptually more sophisticated idea, in a twofold sense. First of all, the definition of the "just" price level is, from an axiological point of view, detached from the "unilateral" perspective that characterizes the first two constructions mentioned above and becomes a function of their interrelation. In other words, this theory is not aimed at patronising a class of economic operators $v i s-\grave{a}-v i s$ the other but at interpreting their reciprocal interplay, instead.

Secondly, in this theory of "just" prices the "individualistic" perspective, focused on the needs and preferences of individual buyers and sellers, is dismissed in favour of a systemic approach. The dominant criterion, in fact, becomes the overlap between the aggregate functions of supply and demand. Such interplay of supply and demand curves makes them recessive both the desire of the individual consumer to purchase and the remuneration of the individual entrepreneur. In this perspective, the inability to buy or sell with profit, far from representing an element in support of the need to fix a different ("more just") price, on the contrary, indicates the inadequacy of the market players suffering from such an inability

considered an abuse of a dominant position by the firm controlling it, in particular where such a denial prevents competition in a downstream market. On this issue under EU law see: Glasl D., Essential Facilities Doctrine in EC antitrust Law; a contribution to the current debate, in ECLR, 1994, p. 306; Furse M., The essential Facilities Doctrine in Community Law, in ECLR, 1995, p. 469; Flynn L., The Essential Facilities Doctrine in the Community Courts, in Commercial Law Practitioner, 1999, p. 245. On this issue see also: OECD, The essential facilities concept, GD(96)113, Paris, 1996, in http://www.oecd.org/ competition/abuse/1920021.pdf; Valletti, T.M.; Estache, A., The theory of access pricing: an overview for infrastructure regulators, The World Bank, 1999.

42 With reference to one rather known case see Case C-179/90, Merci convenzionali porto di Genova SpA v Siderurgica Gabrielli SpA, ECLI:EU:C:1991:464. 
to operate on that market - inadequacy that can lead to support policies ${ }^{43}$, for example, but also to note their inefficiency and to propitiate their exit from the market (which is the principle on which insolvency legislation is built ${ }^{44}$ ).

It may be appropriate to highlight that such a systemic approach is the only one appropriate in order to ground the theory of the "just" price on economic efficiency, which is the main (if not the only) goal of competition law. ${ }^{45}$

43 By way of example, with reference to Italian law, the support in question may concern: measures to support the income of individuals and families [Cazzola, G., Il Reddito di cittadinanza. Commento a dec. legge 28 gennaio 2019 n. 4; legge 28 marzo 2019 n. 26, in Lavoro nella giur., 2019, pp. 446 ff.; Gambaro, L., Le misure di sostegno al reddito delle famiglie con minori, in Minorigiustizia, 2018, pp. 36 ff.; Valente, L., Contrasto alla povertà e promozione del lavoro tra buoni propositi e vecchi vizi, in Dir. rel. ind., 2018, pp. $1081 \mathrm{ff}$.] business support measures [Averardi, A., Incentivi alle imprese e "industria 4.0". Il ritorno delle politiche industriali?, in Giorn. dir. amm., 2017, pp. $625 \mathrm{ff}$.] also through the use of the tax lever [Saponaro, F., La leva fiscale come strumento di "governance" economica dell'eurozona, in Rass. trib., 2019, pp. $353 \mathrm{ff}$.] or to companies with particular characteristics, as regards their object [Zaffanella, A., Il sostegno finanziario dello Stato al cinema e la disattesa attuazione della "Costituzione culturale", in Riv. dir. dei media, 2018, pp. $29 \mathrm{ff}$.] or because of the subjective qualities of its owner [Golino, C., Strumenti giuridici ed incentivi economici a favore dell'imprenditoria giovanile e femminile nel "framework" legislativo nazionale, in Percorsi cost., 2017, pp. 317 ff.].

44 On similar arguments see, limiting reference to a selection among the most recent writings under Italian law: Bassi, A., I presupposti delle procedure concorsuali nel codice della crisi e dellinsolvenza, in Giur. it., 2019, pp. 1948 ff.; Boggio L.,, L'accesso alle procedure di regolazione della crisi o dell'insolvenza, in Giur. it., 2019, pp. 1952 ff.; Bonfante, G., Il nuovo diritto della crisi e dellinsolvenza, in Giur. it., 2019, pp. 1943 ff.; Cardarelli, M.C., Insolvenza e stato di crisi tra scienza giuridica e aziendalistica, in Dir. fall., 2019, pp. 11 ff.; Carratta, A., Il procedimento di apertura delle procedure concorsuali: dalla legge delega al Codice della crisi e dell'insolvenza, in Dir. fall., 2019, pp. 1057 ff.; Fabiani, M., Il codice della crisi di impresa e dellinsolvenza tra definizioni, principi generali e qualche omissione, Nota a Cass. civ. 19 novembre 2018 n. 29742, in Foro it., 2019, I, pp. 162 ff.; Di Cataldo, V.; Rossi, S., Nuove regole generali per $l$ impresa nel nuovo Codice della crisi e dell'insolvenza, in Riv. dir. soc., 2018, I, pp. 745 ff.; Scognamiglio, G., Osservazioni sul disegno di legge delega "per la riforma delle discipline della crisi d'impresa e dell'insolvenza", in Giur. comm., 2016, II, pp. 918 ff.; Ferri jr., G., Lo stato d'insolvenza, in Riv. notariato, 2015, I, pp. $1149 \mathrm{ff}$. .

45 In fact, it was noted that "the dominant paradigm today is that the only goal of the existing antitrust laws is to increase economic efficiency": Lande, R.H., Commentary: Implications of Professor Sherer's Research for the Future of Antitrust, in Washburn L. J. 29, 1990, p. 258. Similarly see: Bork, R., Legislative Intent and the Policy of the Sherman Act, in J.L. \& Econ., 1966, 9, pp. 7 ff.; Posner, R.A., Antitrust Law, II ed., Chicago, 2001; Skitol, R.A., The Shifting Sands of Antitrust Policy: Where it Has Been, Where It is Now, Where it Will Be in its Third Century, in Cornell J.L.Pub. Pol'y, 1999, 9, p. 239; Easterbrook, F., Workable Antitrust Policy, in Mich. L. Rev. 84, 1986, p. 1689; Brodley, J.F., The Economic Goals of Antitrust Efficiency: Consumer Welfare, and Technological Progress, in N.Y.U. L. Rev., 1987, 62, pp. 1020 ff.; Sullivan, L.A., Post Chicago Economics: Economists, Lawyers, Judges, and Enforcement Officials in a less determinate theoretical World, in Antitrust L.J. 63, 1996, p. 669; Devlin, A., Antitrust in an Era of Market Failure, in Harv. J. L. Pub. Pol'y, 33, 2010, pp. 8 ff..

For the sake of completeness one should note that also other goals are sometimes considered relevant, even in the USA: Lande, R.H., Proving the Obvious: The Antitrust Law were Passed to Protect Consumers (not just to increase Efficiency), in Hastings L.J., 1999, pp. 963 ff.; Salop, S.C., Question: What is the Real and Proper Antitrust Welfare Standard? Answer: The true Consumer Welfare Standard, Statement before 
This approach is not as late as it might be considered on a first impression. The idea that prices should, in principle, be exclusive function of the interaction between buyer and seller was already present in Roman law ${ }^{46}$ - with the only exception, if I am not wrong, of the so-called laesio enormis provided for in C.4.44.2. ${ }^{47}$ The awareness that the price of a good represents a function of its supply and demand, in an aggregate perspective, may be observed already in Bernardo Davanzati, in his Lezione delle monete e notizia de' cambi (1588) and is found, again, in Antonio Serra, in his Breve trattato delle cause che possono far abbondare li regni d'oro e d'argento dove non sono miniere (1613).

For the sake of ideological equidistance, it must be noted that adherence to any given religious belief is not determinant as to adherence to one or another theory on the "just" price. In fact, the same idea that there is no valid a priori criterion for defining what the "just" price should be may be also found in the reflections of the Spanish Thomists of the sixteenth century. The jurist Francisco de Vitoria, of the so-called Salamanca school, is among those who have argued the idea that the price fixing mechanism consists in the interaction between supply and demand, without regard to other factors such as costs incurred for remunerating the factors of production. ${ }^{48}$

The intuition that "the just price does not exist before the agreement" 49 and cannot be considered an "intrinsic" quality of things $s^{50}$, therefore, spans for centuries. The conscious formulation of the rule of the encounter between the demand and supply curves, however, conceptually required the awareness of the possibility that the two curves meet; therefore: the complete elaboration of a theory of the demand curve inclined in the opposite direction to that of the supply (inverse relationship between quantity demanded and prices). Among the first conscious observers of

the Antitrust Modernization Commission, Nov. 4, 2005, \$2A; Pitofsky, R., The Political Content of Antitrust, in U. Pa. L. Rev. 127, 1979, p. 1051; Pitofsky, R. (ed.), The Effect of Conservative Economic Analysis on U.S. Antitrust, O.U.P., Oxford, 2008.

46 As one may read in D.35.2.63: "pretia rerum non ex affectione nec utilitate singolorum, sed communiter funguntur". This remark is in de Roover, R., op. cit., note 35, p. 424.

47 Sometimes laesio enormis was understood, however, as evidence that the principle of "justice" of prices was immanent in Roman contract law. On this issue see: Zimmermann, R.. The Roman Law of Obligations: Roman Foundations of the Civilian Tradition, Oxford, Oxford University Press, 1996, pp. 255 ff.; Westbrook, R., The origin of Laesio Enormis, in Rev. Int. Droits de l'Ant., 2008, p. 39.

48 The observation is taken from Arthur Nussbaum, who believed that Francisco de Vitoria was the first thinker to expose (conceptually and not literally) the notions of freedom of trade and freedom of the seas: Nussbaum, A., A concise history of the law of nations, New York, Macmillan, 1947, p. 62.

49 Thomasius, Ch., De Aequitate Cerebrina Legis Secundae Codicis de Rescindenda Venditione, 1706, cap. II, $\$ 26$.

50 For one of the best known and most authoritative exposition on the point see: von Mises, L., Human Action: A Treatise on Economics, New Haven, Yale University Press, 1949, p. 204. 
the law of "decreasing returns" (at the very foundation of a aware theory of price fixing by the market, in its anonymous functioning ${ }^{51}$ ) one may mention Robert Torrens, who mentioned it in his An Essay on the Production of Wealth $(1821)^{52}$, while the rule of "decreasing marginal utility" is attributed, in the history of economic doctrines, to Hermann-Heinrich Gossen, who dealt with it in his Die Entwickelung der Gesetze des menschlichen Verkehrs, und der daraus fließenden Regeln für menschliches Handeln, of 1854.

\subsubsection{The "static" aspects of the interrelation of demand and supply curves: the theory of equilibrium.}

The desire to free the definition of the "just" price from the arbitrariness of individual needs and preferences and the reference to aggregate supply and demand functions determined the entry into economics of mathematical methods. ${ }^{53}$ One may mention, to this respect, the re-elaboration of the rule of decreasing marginal productivity accompanied by the use of differential calculus and mathematical methods, carried out by Johann Heinrich von Thünen in his Der isolirte Staat in Beziehung auf Landwirtschaft und Nationalökonomie (1826).

The evolution of mathematical theories of price soon approached the scientist assumption, born in the Enlightenment era, under which social systems could be represented as complex and measurable "organisms" which, like the human "organism", would naturally tend towards equilibrium and regular (and predictable) functioning. The problem of the "just price" was progressively restated as the problem of "equilibrium" of the price system; in other words: the problem of defining the conditions under which all existing resources can be said to be invested or used in such a way as to maximise marginal utility. ${ }^{54}$

51 Among the further theoretical improvements that have occurred over time, one can mention the formalisation of the concept of "elasticity" of demand or supply of a good (geometrically: its inclination), due to Marshall, A., Principles of Economics, London, Macmillan, 1890.

52 The information is taken from Quadrio Curzio, A.; Scazzieri, R., Rivoluzione industriale ed economia politica, 1817-1848, Bologna, Il Mulino, 1982, pp. $163 \mathrm{f}$.

53 It is worth noting that "mathematisation" represented the natural outcome of marginalistic theories but not an inevitable choice: these theories were also presented according to a "de-mathematised" model, the most authoritative of which is in Wicksteed, P.H., The Common Sense of Political Economy: Including a Study of the Human Basis of Economic Law, London, Macmillian, 1910.

54 The idea of spontaneous equilibrium of the economic system (albeit in the awareness of its eventuality and not absoluteness) is found, for example, in Hume, D., Political Discourses, 1752 and in Say, J.-B., Traité d'économie politique, ou simple exposition de la manière dont se forment les richesses, 1803 . The first "scientist" formulation is that of Petty, W., Political Arithmetick, 1690, who introduced in economic analysis quantitative and statistical investigation tools. On the measurability of economic phenomena cf. also Bentham, J., An Introduction to the Principles of Morals and Legislation, 1780, who proposed the orientation of public choices on the basis of the arithmetic calculation of individual utilities. 
Particularly eloquent of such investigation method is Tableau économique (1758), by François Quesnay; he was a court doctor and used the blood circulation scheme of the human body as a model to represent the circularity of the economic system. Consistently with the methodological assumptions, economy is examined, in this work, as a stationary system,i.e.: the production of wealth, for hypotheses coming from agriculture alone, is fixed as constant over the years. ${ }^{55}$

All these concepts were further elaborated within the neoclassical school of economics, whose founders are considered Carl Menger (Grundsätze der Volkswirthschaftslehre, 1871), William Stanley Jevons (The Theory of Political Economy, 1871) and Léon Walras (Éléments d'économie politique pure, 1874).

The first one, in truth, abandoned mathematical analysis and further developed the philosophical implications of method - from which the theory of "methodological individualism" originated. The last two, on the contrary, remained faithful to the trend of progressive mathematisation of the economy. Indeed, Walras extracted from economic reality "ideal types" ("perfect competition", "ideal demand" etc., as in the physical sciences "ideal gases" and "ideal fluids" were defined) to reach, eventually, a measurable content to the notion of "just price": that which results in a situation of general economic equilibrium, where the marginal utility of the last good purchased for each species is equivalent.

\subsubsection{The "dynamic" aspects of the interrelation of demand and supply curves: the price as an index of "relative scarcity". From the problem of "justice" of the price to the investigation of its "function" within the market economy.}

The use of the "organism" metaphor for understanding and describing economic systems and markets has undoubtedly contributed to a better understanding of reality. It has also imposed an high cost in terms of misunderstanding, which is due whenever rhetorical figures that involve semantic translations (as metaphors) are used in scientific discourse ${ }^{56}$ : that of relying on formalisations based on assumptions which are, by definition, unachievable in the real world and, sometimes, of making uncritical reliance on them. This entails, among others, the methodological risk, highlighted by Milton Friedman in his Nobel lecture of 13 December

\footnotetext{
55 See Cournot, A.A., Recherches sur les principes mathématiques de la théorie des richesses, 1838, whose research can be considered the first example of mathematical economics, as noted by Ricossa, S., Cento trame di classici dell'economia, Milano, Rizzoli, 1991, p. 93. One should note that Cournot used mathematical functions exclusively symbolically, to represent correlations between data elements, and not as tools for measuring real data; in other words, Cournot's reasoning has no econometric implications.

56 Marchisio, E., "Spaccare il capello in quattro". Interpretazione del diritto (commerciale) e figure retoriche, in Giur. comm., 2018, pp. 404 ff..
} 
1976 ${ }^{57}$ : even if one makes many attempts " to patch up the hypothesis by allowing for special factors", it is inevitable that "experience stubbornly [refuses] to conform to the patched up version". ${ }^{58}$

This observation is of elemental importance for the purposes of this research: in fact, the "static" profile, which concerns the study of the elements determining a given level of prices as an interplay between the functions of supply and demand, does not seem to have particular relevance in itself herein - if not as a conceptual reference of principle, with relevance mostly in the long run.

Instead, what appears to be most relevant for the purposes of the present reasoning is the "dynamic" profile thereof, that is: the investigation of price changes, their reasons and the consequences of these changes onto the system. In this sense, by limiting attention not to the absolute value of a price but to its variation over time, one may note that prices act (or, at least, can act) as an "index of scarcity". ${ }^{59}$ This means that changes in (relative) prices allow individuals to make accurate and efficient economic choices based on the actual conditions in place.

Two examples can clarify the above-made statement. Let's imagine that the fruit offer is composed, in a given period, of oranges and grapefruits. Let's imagine that both are offered on the market at the same price, but consumers prefer oranges, which tend to run out quickly, and do not like grapefruits, which instead rot on the shelves. The increase in the price of oranges compared to that of grapefruits represents, in this system, the fastest, most efficient and most practical way of communicating to producers the need to produce more oranges and less grapefruits.

Assume, under a different perspective, that a flooding destroys half of the orange plants. The increase in the price of oranges compared to that of grapefruits represents, in this system, the quickest, most efficient and most practical way of communicating to the market the reduced availability of oranges compared to grapefruits and, downstream, to get this "information" on supermarket shelves without any express disclosure from orange producers.

\footnotetext{
$57 \quad$ It may be read at: http://www.nobelprize.org.

58 Friedman, M.,. Nobel lecture, 1976, in http://www.nobelprize.org, p. 283.

59 Schumpeter, J., History of Economic Analysis, New York, Oxford University Press, 1954, claimed that the first conscious theory under which the value of an asset depends on its relative scarcity was formulated by Galiani, F., Della moneta, libri cinque, Napoli, Giuseppe Raimondi, 1750. See, on this issue: von Hayek, F.A., The use of knowledge in society, in Amer. Econ. Rev., 1945, pp. $519 \mathrm{ff}$.
} 


\section{THE JURIST'S PERSPECTIVE: THE NEED TO “PROTECT” THE FUNCTIONING OF THE PRICE MECHANISM AS AN INDEX OF RELATIVE SCARCITY.}

The function of prices as "messengers" of the relative scarcity of goods and services, just mentioned, represents an elemental component for the functioning of competitive markets. Such a function, instrumental to the correct operation of the economic system, must be protected by the legal system, as it is clear after an even summary overview of the relevant normative context.

The current EU "constitutional" framework disciplines the economy pursuant to the "social market economy" model $\left({ }^{(0)}\right)$, namely: a competitive economy tempered by social considerations. ${ }^{61}$ Such a "social" connotation of the market economy causes that the free-competitive model does not have an absolute nature and admits intervention of public authorities in the economy, both in order to improve the functioning of the market with respect to endogenous anticompetitive dynamics ${ }^{62}$ and as an alternative to the market when derogation is deemed necessary

60 By social market economy one means the economic theory under which the discipline of economic activities should be oriented in order to pursue both market freedom and social justice. It originates from the Ordoliberalism of the School of Freiburg, by Walter Eucken (founder, in 1940, of the magazine Ordo, from which the movement took its name), and found its first theoretical arrangement with Wilhelm Röpke and legal deepening with Hans Grossman- Dörth and Franz Böhm. The basis for this economic doctrine is the idea that economic freedoms are a necessary condition for the full realization of the individual but not yet a sufficient condition. In this sense, it is believed that the State (or similar public bodies with regulatory power) must intervene in order to correct imbalances suitable for limiting the free individual realisation. This doctrine clearly identifies market freedom as a general discipline and limits public corrective actions to correction of market dysfunctions, when the market itself is not suitable for guaranteeing results consistent with the reference social model. On this issue, among the infinite, see: Felice, F., L'economia sociale di mercato, Soveria Mannelli, Rubbettino, 2009; Somma, A., La Germania e l'economia sociale di mercato, Torino, Centro Einaudi, 2014; Prodi, R., Il capitalismo ben temperato, Vol. IV, Bologna, Il Mulino, 1995.

${ }^{61}$ The literature on the subject is practically endless. Among the infinite see: Esping-Andersen, G., The Three Worlds of Welfare Capitalism, Princeton, Princeton University Press, 1990; European Commission, White Paper on the Future of Europe. Reflections and Scenarios for the EU27 by 2025, COM (2017) 2025, 1 March 2017; European Commission, Reflection Paper on the Social Dimension of Europe, COM (2017) 206, 26 April 2017; Gerber, D., Constitutionalising the Economy: German Neo-Liberalism, Competition Law and the "New" Europe", in American Journal of Competition Law, 1994, 42, pp. 25 ff.; Joerges, C.; Rödl, F., "Social Market Economy" as Europe's Social Model?, EUI Working Paper LAW No. 2004/8, 2004; Sangiovanni, A., Solidarity in the European Union, in Oxford J. Legal St., 2013, 33, pp. 213 ff..

62 What has been defined as the defense of the market by itself, which can come to "replicate" competitive conditions otherwise absent or insufficient in a given market: Selznick, P.. Focusing Organizational Research on Regulation. Comments on some Aspects of Public and Private Bureaucracy as They Bear on Regulation, in Noll, R.G. (ed.), Berkeley, University of California Press, 1985, pp. 363 f.. As noted by Giani, L., Attività amministrativa e regolazione di sistema, Torino, Giappichelli, 2002, p. 16: "in this perspective ... the market (rectius the economic system) comes to condition the activities that pertain to the law which, in a certain sense, adapt to it. And so, for example, the same legislative activity, and also the regulatory activity 
to give satisfaction to social and political needs which may not find sufficient satisfaction by the functioning of the "invisible hand" ${ }^{63}$ of anonymous exchanges. ${ }^{64} \mathrm{In}$ other words, the legal system allows public authorities the possibility of intervening in order to reduce negative externalities ${ }^{65}$ or confront politically undesirable outcomes $^{66}$ that could derive from the functioning of a pure laissez-faire system.

These, however, are exceptions to the general rule governing economic activities, according to the model of free competition. ${ }^{67}$ In fact, legitimacy of any public intervention in derogation to the said general rule (either for pro-competitive or "social" purposes) is conditioned, under European law ${ }^{68}$, to respect the principle of proportionality in the broad sense (Verhältnismäßigkeitsprinzip). This was devel-

carried out by public administrations, from "standard training" activities, in a certain sense are transformed into training activities of rules for adaptation to market dynamics, or if you want freedom".

63 According to the well-known metaphor of Smith, A., The Theory of Moral Sentiments, 1759; Smith, A., An Inquiry into the Nature and Causes of the Wealth of Nations, 1776, who, however, used it to represent Providence for which the selfish search for one's interest leads, in the free market, to satisfy the interest of the whole society, thus transforming "private vices" into "public virtues". Subsequently, after Léon Walras and Vilfredo Pareto, the metaphor of the "invisible hand" was commonly used to refer to the economic mechanisms that regulate the market economy in such a way as to ensure that the search for maximum individual satisfaction by individuals produces, at the aggregate level, the well-being of society.

64 According to a parameter of "sufficiency" defined with reference to political, social and cultural benchmarks in force in a given system in a given historical moment. In this second hypothesis, the public intervention is justified by extra-economic intents deemed prevalent or at least equivalent to the principles of the market economy, with which, therefore, it is necessary to carry out a balancing judgment: on the subject see: Celano, B., Diritti, principi e valori nello Stato costituzionale di diritto: tre ipotesi di ricostruzione, 2004, http://www.giuri.unige.it/intro/dipist/digita/filo/testi/analisi_2004/06celano.pdf.

65 Volokh, A., Externalities, in Hamowy, R. (ed.), The Encyclopedia of Libertarianism, Thousand Oaks (CA), SAGE, Cato Institute, 2008, pp. 162 ff.; Laffont, J.-J., Externalities, in The New Palgrave Dictionary of Economics, London, Palgrave Macmillan, 2008; Papandreou, A., Externality and Institutions, Oxford, Oxford University Press, 1998.

${ }_{66}$ Koslowski, P., Principles of Ethical Economy, Dordrecht, Kluwer Academic Publishers, 2001, pp. 6 ff.; Weber, M., Wirtschaft und Gesellschaft, Tübingen, Mohr, 1922.

${ }_{67}$ The "style" of the regulatory activity currently in force in Italy represents the "expression of a different framework of relations" between legal norm and economic facts, legitimised, at the top, by a very precise paradigm, under which the objectives and operating rules of a given market cannot be defined in heteroreferential terms with respect to the market in question: Giani, L., op. cit., note 62, p. 16, where the observation that in this perspective of regulatory intervention "the market (rectius the economic system) affects the activities that pertain to the law which, in a certain sense, adapt to it".

68 Case 182/84 Miro EU:C:1985:470; Case C-331/88 The Queen v Minister of Agriculture, Fisheries and Food and Secretary of State for Health ("Fedesa"), EU:C:1990:391; Case C-180/96 United Kingdom of Great Britain and Northern Ireland v Commission of the European Communities EU:C:1998:192; Cases C-96/03 and C-97/03 A. Tempelman (C-96/03) and Mr and Mrs T.H.J.M. van Schaijk (C97/03) v Directeur van de Rijksdienst voor de keuring van Vee en Vlees EU:C:2005:145. See also the observations of the AG Tesauro (EU:C:1991:69) in Case C-68/89 Commission of the European Communities v Kingdom of the Netherlands EU:C:1991:226. On a regulatory level, see, for the systematic scope of the provision, art. 52 of the Charter of Fundamental Rights of the European Union. 
oped in German law ${ }^{69}$ as a criterion for limiting individual freedoms by public authorities and requires coexistence of a Legitimer Zweck (i.e. justification) with the requirements of Geeignetheit (suitability), Erforderlichkeit (necessity) and Angemessenheit (adequacy).

From this regulatory, but also axiological, context it follows the principle that regulation of economic activities cannot be defined in hetero-referential terms with respect to the markets on which it brings effects. ${ }^{70}$ As far as this research is concerned, this means that, unless the conditions required by the system exist in order to derogate from the functioning of the price-system (only for the temporary pursuit of legitimate purposes), it does not appear possible to produce rules, or interpret the current rules, conflicting with the function of index of relative scarcity of prices.

Paraphrasing the wording used by Ludwig Raiser, it is necessary to take note of how freedom of contract (Vertragsfreiheit) should be recognized, in the economic system, a function (Vertragsfunktion) ${ }^{71}$ within the dynamics of the competitive market - an essential function in a meta-individual and systemic perspective. Consequently, it is necessary that the "justice" of prices is appreciated not as concerns its amount but "as regards the legality of its formation" ${ }^{72}$, in a procedural and dynamic perspective.

69 For implementation of the principles indicated above, in Italy see: Casucci, F., Il sistema giuridico "proporzionale" nel diritto privato comunitario, ESI, Napoli, 2001; Galetta, D.U., Principio di proporzionalità sindacato giurisdizionale nel diritto amministrativo, Milano, Giuffrè, 1988, pp. 11 ff.; Sandulli, A., Proporzionalità, in S. Cassese (ed.), Dizionario di Diritto Pubblico, Vol. V, Milano, Giuffrè, 2006, pp. 4643 ff.; Scaccia, G., Il principio di proporzionalità, in S. Mangiameli (ed.), L'ordinamento europeo, Vol. II, L'esercizio delle competenze, Milano, Giuffrè, 2006, pp. 225 ff..

70 Cfr. Giani, L., op. cit., note 62, p. 16, where the observation that in this perspective of regulatory intervention "the market (rectius the economic system) affects the activities that pertain to the law which, in a certain sense, adapt to it".

71 Raiser, L., Vertragsfunktion und Vertragsfreiheit, in Id., Die Aufgabe des Privatrechts, Regensburg, Athen囚um-Verlag, 1977, pp. 65 ff.. On the apparent incompatibility between any attempt to impose by law a "just price" and the functioning of competitive markets see, in Italy: Lanzillo, R., Regole del mercato e congruità dello scambio contrattuale, in Contr. impr., 1985, pp. 309 f.; Albanese, A., Contratto mercato responsabilità, Milano, Giuffrè, 2008, pp. 98 f. and footnote n. 122.

72 Irti, N., Persona e mercato, in Riv. dir. civ., I, 1995, p. 292; similarly Navarretta, E., Causa e giustizia contrattuale a confronto: prospettive di riforma, in Ric. Dir. civ., I, 2006, pp. 416 ff.. 


\section{BRING PREMISES TO THEIR CONSEQUENCES. THE DISCIPLINE OF PRICE INCREASES “IN TIMES OF CRISIS”.}

If one shares the above-exposed ideas, it seems necessary to devote some further reflection on price increases in times of crisis, examining separately the hypotheses in which these increases result from shifts in either the supply or demand curve.

\subsection{Price increases resulting from shifting of the supply curve. The paradigm of seasonal vegetables in case of adverse weather events.}

The first group of price increases during "crisis" refers to the scenarios where the increase in question results from a reduction of the quantities available for sale. Here the price increase acts as a message to the market of a scarcity of the good or service compared to the other ones available within the market. This is the case, for example, of price increases of seasonal vegetables when adverse weather events destroy a significant part of the crops.

In this instance, the effects (let me underline: beneficial under a systemic perspective) resulting from the price increase are evident and must be kept in mind for the purposes of this research. Imagine an oversimplified market where Titius produces twenty artichokes a year and is able to sell its products at a price of $€ 10$ each, which allows him to cover the fixed costs (in hypothesis: overall $€ 160$ ) and collect a satisfactory profit (in hypothesis: $€ 40$ ). Let's imagine that the products are purchased by only two consumers, Caius and Sempronius, who, at the unit price of $€ 10$, are willing to buy ten artichokes each. Regardless of who gets to the market first, the other finds enough artichokes on the shelf for himself. The market is in balance.

Let us suppose that a flood destroys half of Titius's production. An increase in the unit price of artichokes, hypothetically, to $€ 20$, would have two consequences. The first, more evident, would be that of allowing Titius to continue to cover his fixed costs (which, having already been borne, have remained $€ 160$ ) and to collect his own profit. The second, quite often underestimated, would be that of sharing the available artichokes equally between Caius and Sempronius. In fact, if the unit price remained $€ 10$, the first to arrive at the shop would be willing to buy ten, with the consequence that the second would remain without any. Let us suppose, for simplicity of example, that the elasticity of demand ${ }^{73}$ is such that in

73 The elasticity of demand with respect to the price indicates, in microeconomics (other conditions being equal), the relationship between the percentage change in the quantity demanded and the percentage change in the price. Hypersimplifying: when a $1 \%$ price change generates a demand quantity variation greater than $1 \%$, the demand is defined elastic with respect to the price. When the opposite occurs, that is: a $1 \%$ price change generates a demand quantity variation of less than $1 \%$, the demand 
the face of the doubling of price each of the two buyers is willing to buy half of the artichokes they would have purchased at the previously applied price. Under this condition, when confronted with a unitary price increase to $€ 20$, both Caius and Sempronius would be willing to buy (only) five artichokes each. Following the price increase (and only following the price increase), regardless of who gets to the market first, the other could continue to find a sufficient amount of artichokes on the shelf even for himself.

Obviously the reality is much more complicated than the example recalled above: the relevant parameters are infinitely greater and have a much wider variability. In addition, attribution of the cost of the flood could be distributed in a proportionally different way between producer and consumers, for example by imagining that the price increase is such as to partially reduce the entrepreneur's profit. However, the logic of the example is that, in the hypothesis under consideration, in the absence of an increase in the unitary price of artichokes of at least up to $€$ 16 , the producer Titius would not be able to cover its fixed costs and the distribution of available goods between Caius and Sempronius would, to a greater or lesser extent, depend on who reaches the shelf first.

This means, obviously, that any economic support measure for Titius to keep the unitary price of artichokes at $€ 10$ would be justified only on condition that the demand for Caius and Sempronius was totally inelastic (i.e. in the face of any price increase either of them would prefer not to buy anything) or that the allocation of artichokes between them was regulated in some way (but it is rather likely that any such a regulation would be less efficient than the price increase, this is noted incidentally). Otherwise, imposing or allowing Titius to maintain the prices previously applied would only result in an incentive to hoard: in other words, an invitation to run and buy all the available artichokes before the other does.

\subsection{Price increases resulting from shifting of the demand curve. The paradigm of respiratory protection masks during the coronavirus crisis.}

The hypothesis of price increase reported in the previous $\$ 5.1$, although very often the object of public bewilderment, is however commonly understood and accepted, even by the general public, in light of the fact that Titius, the producer, does not derive any "advantage" from such an increase. On the contrary: at best, he is in the same position it would have been in the absence of the flood; in the worst case, he is forced to renounce (almost) all his profit.

is defined as rigid compared to the price. If a $1 \%$ change in price generates a $1 \%$ change in demand, demand is of unitary elasticity. 
What is commonly presumed unacceptable, however, although often not explicitly, is that the price increase may lead to an increase in the entrepreneur's profit, when it occurs not as a consequence of a decrease in the quantity of goods or services offered onto the market but following a change in consumer preferences - that is: following a shift of the demand curve. This is exactly the case of the increase in the price of respiratory protection masks that occurred on the occasion of the diffusion of COVID-19.

The perceived disapproval of these price increases seems a consequence of a preunderstanding (in the sense, proposed by Gadamer, of Vorverständnis). ${ }^{74}$ Regardless of the origin of such a prejudice (ethical, under which "profit" is seen as a manifestation of selfishness ${ }^{75}$; cognitive, under which, in presence of a threat to self-esteem, people tend to show hostility towards external groups ${ }^{76}$; etc.), the stereotype that any increase in profits amounts to a socially reprehensible event seems to play a relevant role in supporting the conclusion that such increase could, or even should, be considered unlawful.

This is a sociological and cultural issue, of course, not a legal one. However, it is not insignificant for the purposes of legal reflection, given that cognitive sciences confirm ${ }^{77}$ what Piero Calamandrei (an eminent Italian jurist) had already observed in the first half of the twentieth century: "although it continues to be repeated that the sentence can be schematically reduced to a syllogism, in which, from given premises, the judge draws the conclusion for the sole virtue of logic, it sometimes happens that the judge, in forming the sentence, overturns the normal order of the syllogism: that is, it finds first the device and then the premises that serve to justify it ... it means ... that, in judging, intuition and sentiment often have a larger part of what does not seem from the outside" ${ }^{78}$

74 In the sense of pre-understanding (Vorverständnis) which projects on the object of the research the meaning attributed to this object by the subject who interprets it and by the community to which he or she belongs: Gadamer, H.G., Wahrheit und Methode. Grundzüge einer philosophischen Hermeneutik, Tübingen, J.C.B. Mohr (Paul Siebeck) Verlag, 1960.

75 On this point, see the references made to the previous $₫ 3.1$.

76 One for all: Hewstone, M.; Rubin, M.; Willis, H., Intergroup bias, in Ann. Rev. Psych., 2002, pp. 575 ff..

77 Kahneman, D., Thinking, Fast and slow, New York, Farrar, Straus and Giroux, 2011; Mortellini, M.; Guala, F., Mente mercati decisioni, Milano, Università Bocconi Editore, 2011; Bona, C., Sentenze Imperfette, Bologna, Il Mulino, 2010; Bona, C.; Bazzanella, B., L'assegno di mantenimento nella separazione. Un saggio tra diritto e scienze cognitive, Trento, Università degli Studi di Trento, 2008; Guthrie, C.; Rachlinski, J.J.; Wistrich, A.J., Inside the judicial mind, in Cornell Law Rev., 2001, pp. 777 ff.; Kahneman, D.; Slovie, R.; Tversky, A., Judgment under uncertainly. Heuristics and biases, Cambridge, Cambridge University Press, 1982.

78 Calamandrei, P., Elogio dei giudici scritto da un avvocato, 1935. 
However, even if common feeling condemns profit, it should be noted that the event of price increase in question appears, in theoretical terms, absolutely equivalent to that examined under $\$ 5.1$ above, from various points of view. In the first place, at a closer review, price increase of masks from one moment to the other represents, nothing but a variation consequent to a different consumer preference, equivalent to that shown between oranges and grapefruits in the example given in the previous $₫ 4$. The difference is chronological: in the previous case, prices vary because at the same time consumers prefer the good "orange" to the good "grapefruit"; in the present case, prices vary because, at chronologically different times, consumers show a different preference for the same good "mask".

Secondly, in both cases (perhaps: especially in the case in question) price increase represents the appropriate tool to produce an efficient rationing of the goods available for sale. If, in a time of crisis, masks continue to be sold at the normal price, it is highly probable that the first to arrive at the store buys up high quality thereof, leaving others unprotected - exactly what happened in reality. Conversely, a timely increase in prices would determine, if demand is presumed elastic, purchase of a smaller quantity of masks by individual consumers, thus allowing a greater diffusion thereof.

Even under an ethical point of view, efficient rationing following price increases at stake cannot, and should not, be underestimated. It is common feeling, driven by the above-said prejudice, that price increases due to a shift of the demand curve favour the wealthier and leave the poorer worse off. It should also be taken into account that failure to let prices increase would favour alarmists, allowing them to fill up their drawers with masks, leaving the others unprotected. It is maybe easier for public authorities to resolve the first problem, lack of resources to purchase masks by someone, than the second, the scarcity of existing masks.

\subsection{Irrelevance of any entrepreneur's profit increase and of the objections that prices could raise "too much". Legislation against price gouging as a "storm after the storm".}

The arguments upheld under this $₫ 5$ allow to conclude that price increases following a situation of crisis, either due to retrocession of the supply curve (reduction of the available quantities) or to advancement of the demand curve (increase in preference for purchase), are both perfectly rational and, above all, both lead to more efficient allocation outcomes than the alternative consisting in maintaining previous prices. 
In this perspective, the possible increase in profit for the entrepreneur, apparently relevant in an "ethical" perspective, seems instead to be the result of an irrational and dangerous stereotype ${ }^{79}$ - the danger consisting, of course, in a concrete less just allocation of resources as a consequence of adherence to an abstract and only asserted "more just" criterion. Thus, it seems totally irrational and senseless to hold the assumption that the market price is right until proven otherwise $e^{80}$ and to deem that any increase in costs in times of crisis represent evidence valid to this scope: this would mean allowing the price system to report changes in scarcity when it is not needed (in a condition of equilibrium, it is allowed to say with a certain approximation) and, incomprehensibly, to prevent it just when it would be necessary.

It would be irrelevant also to object that, in times of crisis, prices could raise "too much". The "correct" price is the price at which all available goods are purchased. If the purchase is made at a price higher than before, it means that the previous price was too low. If, on the other hand, the price actually becomes too high and reaches a measure to which consumers do not want (or are not able) to buy the product, then it will be rational, for the manufacturer or distributor, to lower the price to the point where no unsold goods remain. This is how market rules work.

In this respect, it ought to be noted that "price gouging" legislation in force in several states within USA showed extremely dangerous to consumers for the reasons evidenced above, since price increases are a rational response to product shortages and their control hinders efficient market functioning, including drawing resources to the affected market. The unwanted effect of prohibition of price gouging, in fact, is that of making market recovery longer and more difficult, since price gouging laws prevent the flow of goods in from other states and, therefore, may harm the people whom they are meant to protect, instead. ${ }^{81}$

\section{A NOTE: SOLIDARITY AND “CORRECTIVE” INTERVENTIONS ARE NEEDED BY PUBLIC AUTHORITIES, NOT PRODUCERS, WHOLESALERS OR RESELLERS.}

At this point it is necessary to dispel a myth. It is often believed that leave price mechanisms operate would amount to disavowing solidarity - which is certainly recognised under EU law, deriving from artt. 8, 9 and 10 TFEU, along with art.

\footnotetext{
79 For a discussion of similar topics in the legal perspective see: Oppo, G., Diritto dellimpresa e morale sociale, in Riv. dir. civ., I, 1992, pp. 15 ff..

80 Koslowski, P., op. cit., note 66, p. 188.

81 Culpepper, D.; Block, W.E., Price gouging in the Katrina aftermath: Free markets at work, in International Journal of Social Economics, 35, 2008, pp. $512 \mathrm{ff.}$.
} 
12, specifically aimed at consumer protection, and from all provisions belonging to title IV ("Solidarity") of the Charter of Fundamental Rights of the European Union, especially art. 35, devoted to health care. This objection, however, makes no sense. If it rains, we never try to stop the rain; we take an umbrella, instead. Price variations signal, at least most of the times, a variation of availability of goods and services. This relates to what happens and has nothing to do with solidarity.

Said in other words, the proposal to let the price fluctuation function as a relative scarcity index does not contradict solidarity duties nor the possibility (or duty) of public authorities to allow access to essential goods in favour of people who cannot afford to purchase them on the market. This is especially true when, as it is the case with COVID-19, availability of some goods (respiratory protection masks and other sanitation products) is necessary also for the protection of metaindividual interests such as protection of health.

It was noted, under $\$ 4.1$ above, that the "social” connotation of the market economy does not advocate an absolute laissez-faire system but, on the contrary, legitimises intervention of public authorities in the economy. This, as also noted, not only in order to improve the functioning of the market with respect to endogenous anticompetitive dynamics but also in order to satisfy social and political issues that would not be considered adequately satisfied in a system of free competition.

This is exactly the field in which solidarity comes into play.

However, this observation requires three clarifications. First, given that the model of free competition represents the general rule of market discipline, any public intervention aimed at avoiding price increases could be said to be legitimate only on condition that the principle of proportionality in the broad sense, already referred to in $\$ 4$ above, is respected, namely: that a constitutionally founded justification occurs (and the protection of public health could certainly be), that the measure is suitable to meet such justification, that the measure is necessary and adequate for its purpose.

By the way, it ought to be noted, any measure of price chilling should not operate by imposing price caps, since in a situation of scarcity price caps reduce supply and create further inefficiencies. One may think, as an example, to the fixing of the price for masks at $€ 0,50$ imposed by Italian Ministry of Health Domenico Arcuri (order n. 11/2020 of 26 April 2020).$^{82}$ Such a measure was intended, of course, to allow distribution of masks at lower prices. Instead, it lowered availability of masks within the Italian market because, among others, distributors were required to sell

82 http://www.governo.it/sites/new.governo.it/files/CSCovid19_Ord_11-2020-txt.pdf. 
masks at a price lower than the price they could purchase masks from producers. ${ }^{83}$ Therefore, any measure aimed at lowering prices for consumers should not be limited to imposing fixed prices on firms but would require public powers to intervene in order either to directly supply goods (even at a price lower than costs, if necessary) or support resellers in order not to impose them losses on each sale.

Secondly, and this is the most relevant note, any public intervention would, in any way, presuppose the previous free and "correct" functioning of the price mechanism. In fact, how would it be possible for public authorities to know the need to intervene for the production of a given good, its provision at "political" prices etc.? Of course, it is unthinkable that government periodically issues questionnaires to all citizens asking what goods are no longer (or in any case less) available on the market. The verification times would be excessively long and unnecessarily expensive. More simply, government would realise that solidarity calls for its intervention by examining price variations: if the price of a given good increases, it means that the demand is increasing on an equal (or less than proportional) increase in supply. If the same price rises rapidly, it means that there is an urgent need to intervene.

Finally, the previous observations determine a fundamental consequence for the purposes of this article. Given that the objective of containing prices is systematically proposed as a derogation from the correct functioning of the market and requires express legislative intervention by the public authorities; and given that the need for such intervention becomes perceptible to the authority exactly by following the correct functioning of the price mechanism (whose functioning, therefore, is necessary in order to solicit public intervention); any fights against firms charging higher prices resulting from this correct functioning appears totally unjustified.

In short: public authorities can contain or even neutralize the increase in prices by several means of extraordinary regulation, but the legal system cannot provide for the imposition of sanctions against firms which only (rationally) adjusted supply conditions to a forward shift in the demand curve.

83 It appears that even the Italian Protezione Civile purchases masks at unitary prices higher than $€ 0,50$ : https://www.infodata.ilsole24ore.com/2020/05/02/mascherine-50-centesimi-prezzi-calmierati-libero-mercato-anche-la-protezione-civile-le-paga-piu/. 


\section{THE ROOM FOR INTERVENTION: NO NEED, AND NO WISH, FOR "ENHANCED” ENFORCEMENT.}

At the end of the above reasoning, I am not claiming that EU competition law does not have any room for sanctioning, under artt. 101(1) or 102 TFEU increases of prices which may be observed in times of crisis. I claim, instead, that enforcement of such rules should not be enhanced when compared to normal times insofar as, in these times of crisis, market conditions may justify under several points of view price increases. Said in other terms: competition law should be applied, even in these times of crisis, as it was applied before, without any "facilitation" in favour of the EU Commission.

This is why I hope that the EU Commission will remain extremely reluctant to pursue exploitative abuse cases, as suggested by Advocate General Wahl in the past, and will carry on them only against truly dominant firms. It is equally desirable that the EU Commission will not further relax its standards for finding a concerted practice between competitors in case of parallel price increase, with the aim of adjusting competition law rules to the (biased) goal of sanctioning price increases as such. I believe that current case-law on concerted practices already abandoned the boundaries of lawfulness dictated by EU law and drew an illegitimate discipline, insofar as it transformed the (once) rebuttable Anic presumption into a (substantially) conclusive presumption, which may be rebutted only by reporting the fact to the relevant competition authority or public distancing within the definition provided by the same ECJ. ${ }^{84}$ There is no reasonable ground to proceed further on this path.

The scope of competition law should not change in times of crisis, as noted by the European Competition Network ${ }^{85}$, the International Competition Network ${ }^{86}$, the $\mathrm{UNCTAD}^{87}$ and the EU Commission itself. ${ }^{88}$ Adaptations may be required to ensure the supply and distribution of scarce products and services that protect the

84 I explained this critical remarks in detail in Marchisio, E., op. cit., note 7, pp. $559 \mathrm{ff}$. .

85 European Competition Network, op. cit., note 4.

86 International Competition Network (2020), Statement, 8 April 2020, in https://www.internationalcompetitionnetwork.org/wp-content/uploads/2020/04/SG-Covid19Statement-April2020.pdf.

87 UNCTAD - UN Conference on Trade and Development, "The UNCTAD urges competition authorities to use all their tools to combat the adverse consequences of COVID-19 in the markets", 8 April 2020, e-Competitions Preview, Art. N 94543.

88 European Commission (2020a), Communication 8 April 2020, Temporary Framework for assessing antitrust issues related to business cooperation in response to situations of urgency stemming from the current COVID-19 outbreak, C(2020) 3200 final, in https://ec.europa.eu/info/sites/info/files/framework communication_antitrust_issues_related_to_cooperation_between_competitors_in_covid-19.pdf; European Commission (2020b), Antitrust rules and coronavirus, in https://ec.europa.eu/competition/ antitrust/coronavirus.html. 
health and safety of all consumers ${ }^{89}$, e.g.: in order to guarantee appropriate supply and distribution of food, health equipments and similar first-need goods and services to the whole population. ${ }^{90}$ In these narrow limits, relaxation of EU competition law is agreeable on; any aggravation thereof would be undesirable, instead.

Besides what just noted, a different case would be that where the advancement of the demand curve, at the macroeconomic level, is caused by dissemination of false or in unfair information. In this case, however, illegality would not derive from the price increase but from the deception that led to the unfounded shift in the demand curve ${ }^{91}$ - which issue is disciplined by consumer protection legislation that is not examined here. ${ }^{92}$

\section{BRIEF CONCLUSIVE REMARKS. UTOPIAN ALTERNATIVES, ETHIC CONCERNS AND PUBLIC FUNCTIONS.}

The institutional choice to adopt a market regulation model in accordance with the principle of free competition is a consequence of the belief that the "market", which is a hypostasis of the autonomous behaviour of millions of autonomous economic operators, determines the best allocation of resources compared to any alternative form of discipline.

89 International Competition Network, op. cit., note 86; European Competition Network, op. cit., note 4; EU Commission, op. cit., note 88; EU Commission, op. cit., note 88.

$90 \quad$ EU Commission, op. cit., note 88; EU Commission, op. cit., note 88.

91 This seems to be the case in the Italian AGCM procedure n. PS11723, suspending the marketing of an antiviral drug "sold for more than 600 euros" and "the darkening of the site https:/Ifarmacocoronavirus.it", in respect of which, however, the problem appears to be that "the drug in question ... is advertised as the" only drug against Coronavirus (COVID-19) "and the" only remedy to fight Coronavirus (COVID-19) "even if, at present, as stated by the world health authorities, there is no effective cure to fight the virus" (https:// www.agcm.it/media/comunicati-stampa/2020/3/PS11723). Likewise, the CODACONS complaint to AGCM, Guardia di Finanza and Postal Police, made public in the press release of 13 March 2020, concerns, among others, "an oxygenator advertised on a website as a" prevention kit "to combat Covid-19, sold for a modest sum of 995.70 euros. A product presented in a deceptive way, because it would suggest that its use could avoid being infected by the virus" (https://codacons.it/coronavirus-truffe-sul-web-codacons-segnala-speculazioni/).

92 In application of the same principle, one may note, making reference, e.g., to the Draft Common Frame of Reference for European private law, that price increases may be scrutinised in a very narrow set of hypotheses, under provisions of oppressive clauses only insofar as price clauses are not drawn up in a simple and understandable way (Study Group on a European Civil Code - Research Group on EC Private Law, Principles, Definitions and Model Rules of European Private Law, draft common frame of reference, München, Sellier, 2009, Sec. II, 9:406(2); see also Comments sub. Sec. II.-9:406, A: “judicial control of the adequacy of the price is incompatibile with the needs of a market economy"). On the other hand, a rich list of remedies is provided for the cases of incorrect information to the counterparty, willfulness, violence and threat (Study Group on a European Civil Code - Research Group on EC Private Law, cit., Sec. II, 7:204-207) - thus, again, reporting the problem of the lawfulness of price settings to that of the correct formation of the agreement. 
If one shares this premise, it appears contradictory and irrational to contrast its operation precisely when its ability to convey relevant information through price changes fully demonstrates its superiority over any alternative hypothesis of economic planning.

The problem with price increases in times of crisis seems to be, in this as in other cases, that of claiming non-existent alternatives, in order to pursue "ethical" intentions which are impractical in reality; so that it should be asked if it is really "ethical" to support actions that lead to worse outcomes than those intended to be countered, only because they are supported with reference to theoretic ethical principles. ${ }^{93}$

It is no coincidence that within the history of contract law any attempt to propose, or impose, a discipline to protect the "just price" invariably failed ${ }^{94}$, since any such attempt amounted to a mere utopia. ${ }^{95}$ Ethics should claim paths of action leading to the highest and most shared welfare reachable in real life; in this research we supported the view that such path of action (of course: in "general" market regulation and not in sectors subject to special regulation, as already observed above), capable of reaching the best "substantial value" available ${ }^{96}$, consists in letting price mechanism work as "index of relative scarcity", which is an elemental condition to efficiency of the economic system as a whole. ${ }^{97}$ This is even truer with respect to competition law, which is expressly aimed at pursuing market efficiency.

It is not uncommon, in times of crisis, to perceive price increases as unfair, believing that all consumers should be able to purchase all the products they need at a price corresponding to that previously practiced. The problem is that, in reality, all the products are not on the market, or are no longer there, and the previous price represented a condition of encounter between the previous demand and the previous offer. Price increase represents a consequence of the displacement of the

93 One may refer, in this regard, to the rhetorical wish to move from the preference of the "useful" to that of the "just", which is found in Keynes, J.M., Economic Possibilities for our Grandchildren, in Id., Essays in persuasion, New York, Norton \& Co., 1963, p. 370, certainly suggestive but unsuitable for rationally establishing a price discipline system. On the contrary, one may think of how much more useful pragmatism can be found in de Mandeville, B., Fable of the Bees: or, Private Vices, Publick Benefits, 1723, where he criticised the hypocrisy of the society of those times and indicated how collective well-being often follows from the individual pursuit of interests deemed instead not virtuous.

94 The remark is in Scalisi, V., Giustizia contrattuale e rimedi: fondamento e limiti di un controverso principio, in Navarretta, E. (ed.), Il diritto europeo dei contratti fra parte generale e norme di settore, Milano, Giuffrè, 2008, p. 257.

95 Vettori, G., Autonomia privata e contratto giusto, in Riv. dir. priv., 2000, p. 24.

96 Koslowski, P., op. cit., note 66, p. 217; Veca, S., Sull'idea di giustizia procedurale, in Riv. filosof., 2001, p. 219.

${ }_{97}$ Barnett, R., A Consent Theory of Contract, in Colum. L. Rev., 1986, pp. $283 \mathrm{ff.}$. 
two curves. Preventing the price increase or threaten firms charging higher prices means worsening the outcome of the distribution of goods among buyers without any advantage - if not the advantage allowed to hoarders to be able to purchase all the stocks available on the market. $^{98}$

Public authorities can do a lot to supply citizens with essential goods at affordable prices. But price adjustments in response to shocks cannot be considered illegal as such and general EU competition law rules should not be relaxed in order to widen the reach of competition authorities. If deemed necessary, public authorities should start a production of goods in a condition of scarcity or have the courage (and take responsibility) to expropriate the products on the market or even the means of production necessary to produce them; but it is unacceptable to sanction private firms by attributing them the wrong of not having substituted, at their own expense, for the exercise of a public function. ${ }^{99}$

Also because, as noted, if prices did not rise ... probably the public authorities would not notice the need for their intervention. And stocks would run out earlier, to the benefit of a small number of buyers, without having had the opportunity to intervene promptly with any support measures that may be necessary.

\section{REFERENCES}

\section{BOOKS AND ARTICLES}

1. Addy, G. et all., Antitrust Legislation and Policy in a Global Economic Crisis - A Canadian Perspective, in GCP - The Online Magazine for Global Competition Policy, 15.12.2008

2. Albanese, A., Contratto mercato responsabilità, Milano, Giuffrè, 2008

3. Ambrosetti, G., Diritto privato ed economia nella Seconda Scolastica, in Grossi, P. (ed.), La seconda scolastica nella formazione del diritto privato moderno - Quaderni fiorentini per la storia del pensiero giuridico moderno, Milano, Giuffrè, 1973, pp. 23-52

4. Averardi, A., Incentivi alle imprese e "industria 4.0". Il ritorno delle politiche industriali?, in Giorn. dir. amm., 2017, pp. 625-633

98 Regardless of the intentions, in fact, the decision on whether or not to adopt a regulatory choice should be made on the basis of the consequences that it is rational to expect to achieve from that choice. As noted by Milton Friedman in his aforementioned Nobel lecture of 13 December 1976: "in order to recommend a course of action to achieve an objective, we must first know whether that course of action will in fact promote the objective. Positive scientific knowledge that enables us to predict the consequences of a possible course of action is clearly a prerequisite for the normative judgment whether that course of action is desirable. The Road to Hell is paved with good intentions, precisely because of the neglect of this rather obvious point": Friedman, M., op. cit., note 58, p. 268.

99 On similar issues, in principle, see also: Minervini, G., Contro la funzionalizzazione’ dell'impresa privata, in Riv. dir. civ., I, 1958, p. 618; Oppo, G., Liniziativa economica privata, in Riv. dir. civ., I, 1988, p. 309. 
5. Baldwin, J.W., The Medieval Theories of the Just Price: Romanists, Canonists, and Theologians in the Twelfth and Thirteenth Centuries, American Philosophical Society, Philadelphia, 1959

6. Barnett, R., A Consent Theory of Contract, in Colum. L. Rev., 1986, pp.269-321

7. Bassi, A., I presupposti delle procedure concorsuali nel codice della crisi e dell'insolvenza, in Giur. it., 2019, pp. 1948-1952

8. Bassi G., Prezzi e tariffe nei servizi di pubblica utilità: cenni sull'evoluzione ordinamentale, in App. e contr., 2016, pp. 74-84

9. Bentham, J., An Introduction to the Principles of Morals and Legislation, 1780

10. Boggio L., L'accesso alle procedure di regolazione della crisi o dell'insolvenza, in Giur. it., 2019, pp. 1952-1970

11. Bona, C., Sentenze Imperfette, Bologna, Il Mulino, 2010

12. Bona, C.; Bazzanella, B., L'assegno di mantenimento nella separazione. Un saggio tra diritto e scienze cognitive, Trento, Università degli Studi di Trento, 2008

13. Bonfante, G., Il nuovo diritto della crisi e dell'insolvenza, in Giur. it., 2019, p. 1943

14. Bork, R., Legislative Intent and the Policy of the Sherman Act, in J.L. \& Econ., 1966, 9, pp. 1943-1948

15. Brenner, Y.S., Capitalism, Competition and Economic Crisis: Structural Changes in Advanced Industrialized Countries, Wheatsheaf Books, 1984

16. Brodley, J.F., The Economic Goals of Antitrust Effciency: Consumer Welfare, and Technological Progress, in N.Y.U. L. Rev., 1987, 62, pp. 1020-1053

17. Calamandrei, P., Elogio dei giudici scritto da un avvocato, 1935

18. Cardarelli, M.C., Insolvenza e stato di crisi tra scienza giuridica e aziendalistica, in Dir. fall., 2019, pp. 11-31

19. Carratta, A., Il procedimento di apertura delle procedure concorsuali: dalla legge delega al Codice della crisi e dell'insolvenza, in Dir. fall., 2019, pp. 1057-1090

20. Cary, G.S. et all., Exploitative abuses, price gouging \& COVID-19: The cases pursued by EU and national competition authorities, 30 April 2020, e-Competitions Competition Law \& Covid-19, Art. No 94392

21. Casucci, F., Il sistema giuridico "proporzionale" nel diritto privato comunitario, ESI, Napoli, 2001

22. Cazzola, G., Il Reddito di cittadinanza. Commento a dec. legge 28 gennaio 2019 n. 4; legge 28 marzo 2019 n. 26, in Lavoro nella giur., 2019, pp. 446-460

23. Cournot, A.A., Recherches sur les principes mathématiques de la théorie des richesses, 1838

24. Crane, D., Antitrust Enforcement During National Crises: An Unhappy History, in GCP - The Online Magazine for Competition Policy, 15.12.2008

25. Culpepper, D.; Block, W.E., Price gouging in the Katrina aftermath: Free markets at work, in International Journal of Social Economics, 35, 2008, pp. 512-520

26. Derenne, J.; Merola, M.; Rivas, J. (eds.), Competition law in times of economic crisis : in need of adjustment?, GCLC Annual Conference Series, Bruylant / LGDJ, 2013

27. de Roover, R., The Concept of the Just Price: Theory and Economic Policy, in Journ. Econ. Hist., 1958, pp. 418-434 
28. Devlin, A., Antitrust in an Era of Market Failure, in Harv. J. L. Pub. Pol'y, 33, 2010, pp. 557-606

29. Di Cataldo, V.; Rossi, S., Nuove regole generali per l impresa nel nuovo Codice della crisi e dell'insolvenza, in Riv. dir. soc., 2018, I, pp. 745-782

30. Di Matteo, L.A., Equitables Law of Contracts: Standards and Principles, Transnational Publishers, Ardsley (NY), 2001

31. Drauz, G. et all., Recent Developments in E.C. Merger Control, Journal of Eur. Comp. Law \& Pract., 2010, 1, pp. 12-26

32. Easterbrook, F., Workable Antitrust Policy, in Mich. L. Rev. 84, 1986, pp. 1696-1713

33. Esping-Andersen, G., The Three Worlds of Welfare Capitalism, Princeton, Princeton University Press, 1990

34. Fabiani, M., Il codice della crisi di impresa e dell'insolvenza tra definizioni, principi generali e qualche omissione, Nota a Cass. civ. 19 novembre 2018 n. 29742, in Foro it., 2019, I, pp. 162-169

35. Felice, F., L'economia sociale di mercato, Soveria Mannelli, Rubbettino, 2009

36. Ferri jr., G., Lo stato d'insolvenza, in Riv. notariato, 2015, I, pp. 1149-1184

37. Flynn L., The Essential Facilities Doctrine in the Community Courts, in Commercial Law Practitioner, 1999, pp. 245

38. Furse, M., The essential Facilities Doctrine in Community Law, in ECLR, 1995, pp. 469-473

39. Gadamer, H.G., Wahrheit und Methode. Grundzüge einer philosophischen Hermeneutik, Tübingen, J.C.B. Mohr (Paul Siebeck) Verlag, 1960

40. Galetta, D.U., Principio di proporzionalità sindacato giurisdizionale nel diritto amministrativo, Milano, Giuffrè, 1988

41. Galiani, F., Della moneta, libri cinque, Napoli, Giuseppe Raimondi, 1750

42. Gambaro, L., Le misure di sostegno al reddito delle famiglie con minori, in Minorigiustizia, 2018, pp. 36-44

43. Gerber, D., Constitutionalising the Economy: German Neo-Liberalism, Competition Law and the "New" Europe", in American Journal of Competition Law, 1994, pp. 25-84

44. Giani, L., Attività amministrativa e regolazione di sistema, Torino, Giappichelli, 2002

45. Glasl, D., Essential Facilities Doctrine in EC antitrust Law; a contribution to the current debate, in ECLR, 1994, pp. 306-314

46. Golino, C., Strumenti giuridici ed incentivi economici a favore dell'imprenditoria giovanile e femminile nel "framework" legislativo nazionale, in Percorsi cost., 2017, pp. 317-332

47. Guthrie, C.; Rachlinski, J.J.; Wistrich, A.J., Inside the judicial mind, in Cornell Law Rev., 2001, pp. 777-830

48. Harris jr., H.S. et all., China: Korea Considers Antitrust Exemptions for Certain Cartels to Assist Economic Recovery, in www.mondaq.com, Jan. 2009

49. Hewstone, M.; Rubin, M.; Willis, H., Intergroup bias, in Ann. Rev. Psych., 2002, pp. 575604

50. Hume, D., Political Discourses, 1752

51. Irti, N., Persona e mercato, in Riv. dir. civ., I, 1995, pp. 289-298 
52. Joerges, C.; Rödl, F., “Social Market Economy” as Europe’s Social Model?, EUI Working Paper LAW No. 2004/8, 2004

53. Kahneman, D., Thinking, Fast and slow, New York, Farrar, Straus and Giroux, 2011

54. Kahneman, D.; Slovie, R.; Tversky, A., Judgment under uncertainly. Heuristics and biases, Cambridge, Cambridge University Press, 1982

55. Katz, M. et all., Antitrust in a Financial Crisis - A Canadian Perspective, in www.antitrustsource.com, Apr. 2009

56. Keynes, J.M., Economic Possibilities for our Grandchildren, in Id., Essays in persuasion, New York, Norton \& Co., 1963

57. Kleiman E., Just Price in talmudic Literature, in Hist. Polit. Econ. 1987, pp. 23-45

58. Kokkoris, I. et al., Antitrust Law amidst Financial Crises, C.U.P., Cambridge, 2010

59. Koslowski, P., Principles of Ethical Economy, Dordrecht, Kluwer Academic Publishers, 2001

60. Kroes N., Competitiveness - The Common Goal of Competition and Industrial Policies, Address at the Aspen Institute (Apr. 18, 2008)

61. Laffont, J.-J., Externalities, in The New Palgrave Dictionary of Economics, London, Palgrave Macmillan, 2008

62. Lande, R.H., Proving the Obvious: The Antitrust Law were Passed to Protect Consumers (not just to increase Efficiency), in Hastings L.J., 1999, 959

63. Lande, R.H., Commentary: Implications of Professor Sherer's Research for the Future of Antitrust, in Washburn L. J. 29, 1990, pp. 256

64. Lanzillo, R., Regole del mercato e congruità dello scambio contrattuale, in Contr. impr., 1985, pp. 309

65. Lazda, A.R.B. et all., The World's Authorities present steps to minimise the impact of COVID-19 on antitrust related issues that businesses may confront in the coming days of the outbreak, 9 March 2020, e-Competitions Preview, Art. Nº 93889

66. Libertini, M., Diritto della concorrenza dell'Unione Europea, Milano, Giuffrè, 2014

67. Lowe, P., Keeping Markets Working Effectively: Europe's Challenge in Recessionary Times, European Competition Day, Brno, 14.5.2009

68. Mandeville, B., Fable of the Bees: or, Private Vices, Publick Benefits, 1723

69. Marchisio, E., "Spaccare il capello in quattro". Interpretazione del diritto (commerciale) e figure retoriche, in Giur. comm., 2018, pp. 404-423

70. Marchisio, E., From concerted practices to "invitations to collude", in ECLR, 2017, pp. 555566

71. Marchisio, E., Critical Remarks on Collective Dominant Position in EU and Italian Antitrust Law, in ECLR, 2013, 11, pp. 559-569

72. Marshall, A., Principles of Economics, London, Macmillan, 1890

73. Mccall, J., Learning from Our History: Evaluating the Modern Housing Finance Market in Light of Ancient Principles of Justice, South Car. Law Rev., 2009, pp. 707

74. Minervini, G., Contro la funzionalizzazione' dell'impresa privata, in Riv. dir. civ., I, 1958, pp. 618

75. Mortellini, M.; Guala, F., Mente mercati decisioni, Milano, Università Bocconi Editore, 2011 
76. Navarretta, E., Causa e giustizia contrattuale a confronto: prospettive di riforma, in Ric. Dir. civ., 2006, I, pp. 411-436

77. Noonan jr, J.T., The Scholastic Analysis of Usury, Harvard University Press, Cambridge (MA), 1957

78. Nussbaum, A., A concise history of the law of nations, New York, Macmillan, 1947

79. Oppo, G., Diritto dell'impresa e morale sociale, in Riv. dir. civ., I, 1992, pp. 15-36

80. Oppo, G., L’iniziativa economica privata, in Riv. dir. civ., I, 1988, pp. 309

81. Padilla, J. et al., Competition policy and the Covid-19 opportunity, 20 April 2020, Concurrences $N^{\circ} 2-2020$, Art. $N^{\circ} 94317$

82. Palmieri, A., Somministrazione di energia elettrica e servizio di maggior tutela per l'utente, Nota a ord. Trib. Nola 15 novembre 2010, in Foro it., 2011, I, pp. 246-247

83. Papandreou, A., Externality and Institutions, Oxford, Oxford University Press, 1998

84. Perrone, A., Doctrine of the right price and contemporary contract law. Some preliminary reflections, in Campobasso, M.; Cariello, V.; Di cataldo, V.; Guerrera, F.; Sciarrone Alibrandi, A. (eds.), Companies, banks and business crises. Liber amicorum Pietro Abbadessa, Utet, Torino, 2014

85. Petty, W., Political Arithmetick, 1690

86. Pitofsky, R. (ed.), The Effect of Conservative Economic Analysis on U.S. Antitrust, O.U.P., Oxford, 2008

87. Pitofsky, R., The Political Content of Antitrust, in U. Pa. L. Rev. 127, 1979, pp. 1051

88. Posner, R.A., Antitrust Law, II ed., Chicago, 2001

89. Prodi, R., Il capitalismo ben temperato, Vol. IV, Bologna, Il Mulino, 1995

90. Quadrio Curzio, A.; Scazzieri, R., Rivoluzione industriale ed economia politica, 1817-1848, Bologna, Il Mulino, 1982

91. Raiser, L., Vertragsfunktion und Vertragsfreiheit, in Id., Die Aufgabe des Privatrechts, Regensburg, Athenäum-Verlag, 1977

92. Ricossa, S., Cento trame di classici dell'economia, Milano, Rizzoli, 1991

93. Salop, S.C., Question: What is the Real and Proper Antitrust Welfare Standard? Answer: The true Consumer Welfare Standard, Statement before the Antitrust Modernization Commission, Nov. 4, 2005, \$2A

94. Sandulli, A., Proporzionalità, in S. Cassese (ed.), Dizionario di Diritto Pubblico, Vol. V, Milano, Giuffrè, 2006, pp. 4643-4650

95. Sangiovanni, A., Solidarity in the European Union, in Oxford J. Legal St., 2013, 33, pp. 213241

96. Saponaro, F., La leva fiscale come strumento di "governance" economica dell'eurozona, in Rass. trib., 2019, pp. 353-393

97. Say, J.-B., Traité d'économie politique, ou simple exposition de la manière dont se forment les richesses, 1803

98. Scaccia, G., Il principio di proporzionalità, in S. Mangiameli (ed.), L'ordinamento europeo, Vol. II, L'esercizio delle competenze, Milano, Giuffrè, 2006 
99. Scalisi, V., Giustizia contrattuale e rimedi: fondamento e limiti di un controverso principio, in Navarretta, E. (ed.), Il diritto europeo dei contratti fra parte generale e norme di settore, Milano, Giuffrè, 2008, pp. 253-288

100.Schumpeter, J., History of Economic Analysis, New York, Oxford University Press, 1954

101.Scognamiglio, G., Osservazioni sul disegno di legge delega "per la riforma delle discipline della crisi d'impresa e dell'insolvenza", in Giur. comm., 2016, II, pp. 918-926

102. Selznick, P.. Focusing Organizational Research on Regulation. Comments on some Aspects of Public and Private Bureaucracy as They Bear on Regulation, in Noll, R.G. (ed.), Berkeley, University of California Press, 1985, pp. 363-368

103. Shapiro, C., Competition Policy in Distressed Industries, speech delivered at the ABA Antitrust Symposium: Competition as Public Policy, 13.5.2009

104.Skitol, R.A., The Shifting Sands of Antitrust Policy: Where it Has Been, Where It is Now, Where it Will Be in its Third Century, in Cornell J.L.Pub. Pol'y, 1999, 9, pp. 239

105.Smerchinich, F., Il mercato dell'energia elettrica: descrizione, funzionamento e dinamiche, in Riv. it. dir. pubbl. comunitario, 2017, pp. 1269-1310

106. Smith, A., An Inquiry into the Nature and Causes of the Wealth of Nations, 1776

107. Smith, A., The Theory of Moral Sentiments, 1759

108. Sokol, D., The Financial Crisis and its Effects on Antitrust, in Antitrust \& Competition Policy Blog, 18.12.2008

109.Somma, A., La Germania e l'economia sociale di mercato, Torino, Centro Einaudi, 2014

110.Study Group on a European Civil Code - Research Group on EC Private Law, Principles, Definitions and Model Rules of European Private Law, draft common frame of reference, München, Sellier, 2009

111. Sullivan, L.A., Post Chicago Economics: Economists, Lawyers, Judges, and Enforcement Officials in a less determinate theoretical World, in Antitrust L.J. 63, 1996, pp. 669

112.(St.) Thomas, Summa Theologiae, 1273

113. Thomasius, Ch., De Aequitate Cerebrina Legis Secundae Codicis de Rescindenda Venditione, 1706

114.UNCTAD - UN Conference on Trade and Development, "The UNCTAD urges competition authorities to use all their tools to combat the adverse consequences of COVID-19 in the markets", 8 April 2020, e-Competitions Preview, Art. N 94543

115.Valente, L., Contrasto alla povertà e promozione del lavoro tra buoni propositi e vecchi vizi, in Dir. rel. ind., 2018, pp. 1081-1113

116. Valletti, T.M.; Estache, A., The theory of access pricing: an overview for infrastructure regulators, The World Bank, 1999

117.Veca, S., Sull'idea di giustizia procedurale, in Riv. filosof., 2001, pp. 219

118. Vettori, G., Autonomia privata e contratto giusto, in Riv. dir. priv., 2000, pp. 20-50

119.Volokh, A., Externalities, in Hamowy, R. (ed.), The Encyclopedia of Libertarianism, Thousand Oaks (CA), SAGE, Cato Institute, 2008

120.von Hayek, F.A., The use of knowledge in society, in Amer. Econ. Rev., 1945, pp. 519-530 
121.von Mises, L., Human Action: A Treatise on Economics, New Haven, Yale University Press, 1949

122. Weber, M., Wirtschaft und Gesellschaft, Tübingen, Mohr, 1922

123. Westbrook, R., The origin of Laesio Enormis, in Rev. Int. Droits de l'Ant., 2008, pp. 39-52

124. Whish, R.; Bailey, D., Competition Law, VIII ed., Oxford University Press, 2015

125.Wicksteed, P.H., The Common Sense of Political Economy: Including a Study of the Human Basis of Economic Law, London, Macmillian, 1910

126.Zaffanella, A., Il sostegno finanziario dello Stato al cinema e la disattesa attuazione della "Costituzione culturale", in Riv. dir. dei media, 2018, pp. 332-361

127.Ziliotti, M., I prezzi di accesso alle reti dei servizi di pubblica utilità: una sintesi teorica, in Econ. e pol. Ind., 2007, pp. 147-172

128.Zimmermann, R.. The Roman Law of Obligations: Roman Foundations of the Civilian Tradition, Oxford, Oxford University Press, 1996

\section{COURT OF JUSTICE OF THE EUROPEAN UNION}

1. Opinion of AG Bobek in Case C228/18, Gazdasági Versenyhivatal $v$ Budapest Bank Nyrt. and others, ECLI:EU:C:2019:678

2. Opinion of AG Wahl in Case C177/16, Biedrība 'Autortiesību un komunicěšanās konsultāciju aǵentūra - Latvijas Autoru apvienība’ $v$ Konkurences padome, ECLI:EU:C:2017:286, $\$ 3$.

3. Cases C-96/03 and C-97/03 A. Tempelman (C-96/03) and Mr and Mrs T.H.J.M. van Schaijk (C-97/03) v Directeur van de Rijksdienst voor de keuring van Vee en Vlees EU:C:2005:145

4. Case C-180/96 United Kingdom of Great Britain and Northern Ireland v Commission of the European Communities EU:C:1998:192

5. Case C-235/92 P, Montecatini v Commission, ECLI:EU:C:1999:362

6. Case C-199/92 P, Hüls AG v Commission (Polypropylene), ECLI:EU:C:1999:358

7. Case C-49/92 P, Commission v Anic Partecipazioni, ECLI:EU:C:1999:356

8. Case C-179/90, Merci convenzionali porto di Genova SpA v Siderurgica Gabrielli SpA, ECLI:EU:C:1991:464

9. AG Tesauro (EU:C:1991:69) in Case C-68/89 Commission of the European Communities v Kingdom of the Netherlands EU:C:1991:226

10. Joined Cases 110/88, 241/88 and 242/88, François Lucazeau and others v Société des Auteurs, Compositeurs et Editeurs de Musique (SACEM) and others, ECLI:EU:C:1989:326

11. Case C-331/88 The Queen v Minister of Agriculture, Fisheries and Food and Secretary of State for Health ("Fedesa"), EU:C:1990:391

12. Case 182/84 Miro EU:C:1985:470

13. Case 172/80, Züchner v Bayerische Vereinsbank, ECLI:EU:C:1981:178

14. Case C-27/76 United Brands v Commission, ECLI:EU:C:1978:22

15. Case C-26/75 General Motors v Commission, ECLI:EU:C:1975:150

16. Joined cases C-40-48, 50, 54-56, 111, 113-114/73, Suiker Unie et all. v Commission, ECLI:EU:C:1975:174, \$ 173 
17. Case C48/69, Imperial Chemical Industries Ltd. v Commission (Dyestuff), ECLI:EU:C:1972:70

\section{EU LAW}

1. Communication from the EU Commission of 8 April 2020, Temporary Framework for assessing antitrust issues related to business cooperation in response to situations of urgency stemming from the current COVID-19 outbreak, C(2020) 3200 final, $\$ 20$, in https://ec.europa.eu/ info/sites/info/files/framework_communication_antitrust_issues_related_to_cooperation_ between_competitors_in_covid-19.pdf

2. Communication from the Commission - Guidance on the Commission's enforcement priorities in applying Article 82 of the EC Treaty to abusive exclusionary conduct by dominant undertakings (2009/C 45/02)

3. Digesta

4. European Commission, Notice on agreements of minor importance which do not appreciably restrict competition under Article 101(1) of the Treaty on the Functioning of the European Union (De Minimis Notice) (2014/C 291/01)

5. The Holy Bible

6. European Commission, White Paper on the Future of Europe. Reflections and Scenarios for the EU27 by 2025, COM (2017) 2025, 1 March 2017

7. European Commission, Reflection Paper on the Social Dimension of Europe, COM (2017) 206, 26 April 2017

8. Commission Decision n. 77/327/EEC of 19 April 1977 relating to a proceeding under art. 86 of the EEC Treaty (IV/28.841 - ABG/Oil companies operating in the Netherlands), in OJ L 117, 9.5.1977, p. 1 .

\section{LIST OF NATIONAL REGULATIONS, ACTS AND COURT DECISIONS}

1. Italian law 14 November 1995, n. 481

2. US Supreme Court, Verizon Communications Inc. v. Law Offices of Curtis V. Trinko, LLP, 540 U.S. 398 (2004), 13.1.2004

\section{WEBSITE REFERENCES}

1. European Competition Network, Join Statement, 23 March 2020, in https://ec.europa.eu/ competition/ecn/202003_joint-statement_ecn_corona-crisis.pdf

2. https:/www.clearygottlieb.com/news-and-insights/publication-listing/exploitative-abuseof-dominance-and-price-gouging-in-times-of-crisis

3. OECD, The essential facilities concept, GD(96)113, Paris, 1996, in http://www.oecd.org/ competition/abuse/1920021.pdf

4. Friedman, M.,. Nobel lecture, 1976, in http://www.nobelprize.org

5. Celano, B., Diritti, principi e valori nello Stato costituzionale di diritto: tre ipotesi di ricostruzione, 2004, http://www.giuri.unige.it/intro/dipist/digita/filo/testi/analisi_2004/06celano.pdf 
6. Italian Ministry of Health, order n. 11/2020 of 26 April 2020, http://www.governo.it/sites/ new.governo.it/files/CSCovid19_Ord_11-2020-txt.pdf

7. https:/www.infodata.ilsole24ore.com/2020/05/02/mascherine-50-centesimi-prezzi-calmierati-libero-mercato-anche-la-protezione-civile-le-paga-piu/

8. International Competition Network (2020), Statement, 8 April 2020, in https://www.internationalcompetitionnetwork.org/wp-content/uploads/2020/04/SG-Covid19StatementApril2020.pdf

9. European Commission, Communication 8 April 2020, Temporary Framework for assessing antitrust issues related to business cooperation in response to situations of urgency stemming from the current COVID-19 outbreak, C(2020) 3200 final, 2020, https://ec.europa.eu/info/sites/ info/files/framework_communication_antitrust_issues_related_to_cooperation_between_ competitors_in_covid-19.pdf

10. European Commission, Antitrust rules and coronavirus, 2020, https://ec.europa.eu/competition/antitrust/coronavirus.html

11. AGCM procedure n. PS11723, (https://www.agcm.it/media/comunicati-stampa/2020/3/ PS11723

12. https://codacons.it/coronavirus-truffe-sul-web-codacons-segnala-speculazioni/ 